\title{
The Development of Current Collection in Micro-Tubular Solid Oxide Fuel Cells-A Review
}

\author{
Oujen Hodjati-Pugh ${ }^{1}$, Aman Dhir ${ }^{2}$ (D) and Robert Steinberger-Wilckens ${ }^{1, *(D)}$ \\ 1 Centre for Hydrogen and Fuel Cell Research, School of Chemical Engineering, University of Birmingham, \\ Birmingham B15 2TT, UK; O.Hodjati-pugh@pgr.bham.ac.uk \\ 2 School of Chemical Engineering, University of Wolverhampton, Wolverhampton WV1 1LY, UK; \\ aman.dhir@wlv.ac.uk \\ * Correspondence: R.SteinbergerWilckens@bham.ac.uk; Tel.: +44-121-415-8169
}

check for updates

Citation: Hodjati-Pugh, O.; Dhir, A.; Steinberger-Wilckens, R. The Development of Current Collection in Micro-Tubular Solid Oxide Fuel Cells-A Review. Appl. Sci. 2021, 11, 1077. https://doi.org/10.3390/ app11031077

Received: 4 December 2020

Accepted: 20 January 2021

Published: 25 January 202

Publisher's Note: MDPI stays neutral with regard to jurisdictional claims in published maps and institutional affiliations.

Copyright: (c) 2021 by the authors. Licensee MDPI, Basel, Switzerland. This article is an open access article distributed under the terms and conditions of the Creative Commons Attribution (CC BY) license (https:// creativecommons.org/licenses/by/ $4.0 /)$.
Featured Application: This study provides an extensive review of current collection in microtubular solid oxide fuel cells (SOFCs). The state-of-the-art designs are compared using defined key performance met-rics. The design trade-offs between internal and external current collectors are explored. The effects of current collector design, size, spacing and location on cell performance are discussed.

Abstract: Micro-tubular solid oxide fuel cells ( $\mu$ T-SOFCs) are suited to a broad range of applications with power demands ranging from a few watts to several hundred watts. $\mu$ T-SOFCs possess inherently favourable characteristics over alternate configurations such as high thermo-mechanical stability, high volumetric power density and rapid start-up times, lending them particular value for use in portable applications. Efficient current collection and interconnection constitute a bottleneck in the progression of the technology. The development of current collector designs and configuration reported in the literature since the inception of the technology are the focus of this study.

Keywords: micro-tubular SOFC; current collection; interconnection; ohmic polarisation; conduction pathway length

\section{Introduction to Fuel Cell Technology}

Fuel cells are highly efficient electrochemical conversion devices that directly extract electrical energy from hydrogen and hydrogen-rich fuels [1-4]. The stackable/scalable, modular nature of fuel cells suits them to a broad range of applications, ranging from a few watts in portable power devices to several megawatts in backup and peaking power units [5-7]. The first commercial fuel cells were alkaline fuel cells (AFCs) used by the NASA space exploration programmes for providing power to space capsules [8]. Since then, fuel cells have been used in many applications, broadly categorised into portable, stationary and transport markets. Low-temperature fuel cells can use lightweight materials such as plastics and polymers. The fast start-up time and simple heating system required to reach the low operating temperatures of around $80^{\circ} \mathrm{C}$ are the reasons they are favoured in the automotive and portable power sectors. Phosphoric Acid Fuel Cells (PAFCs), Molten Carbonate Fuel Cells (MCFCs) and SOFCs are typically employed for stationary applications such as power generation, grid backup and combined heat and power (CHP). This is due to the increasing time and system complexity/size required to reach the higher operating temperatures and the benefit of having higher efficiency and higher fuel flexibility. However, SOFC technology has been proven to also be functional in the portable and transport sectors [9-11].

The number of fuel cell units shipped over the last five years (2019 included as a partial forecast) for each sector is seen in Figure 1a [12]. In 2018, 68,500 fuel cell units were shipped, $76 \%$ of which were in the stationary sector, $16 \%$ were employed in transport and 
$8 \%$ were for portable applications. Out of the units shipped in 2018, 75\% were in Asia. Japan contributes strongly to the fuel cell market-particularly for the stationary sector, where SOFCs are increasingly being adopted for domestic and commercial CHP and more than 100,000 units have been installed in Japan within the EneFarm programme [13]. The next largest markets with respect to units shipped are North America, followed by Europe.

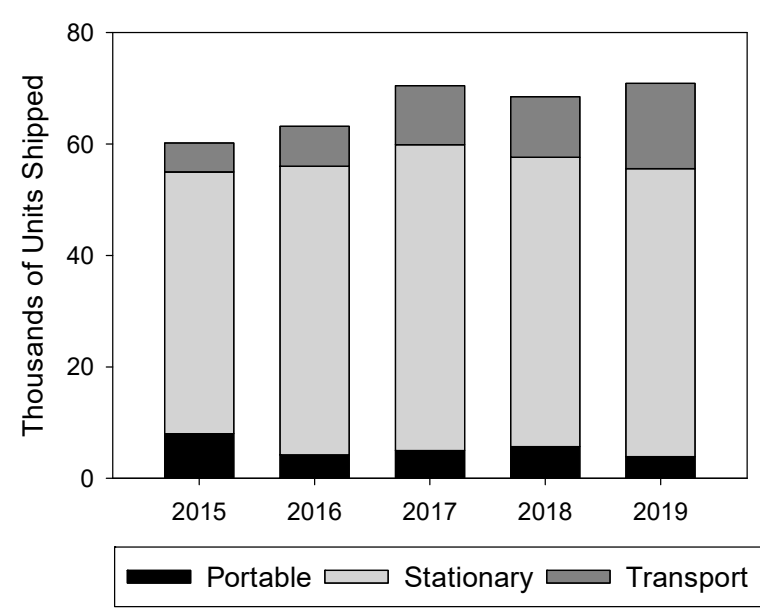

(a)

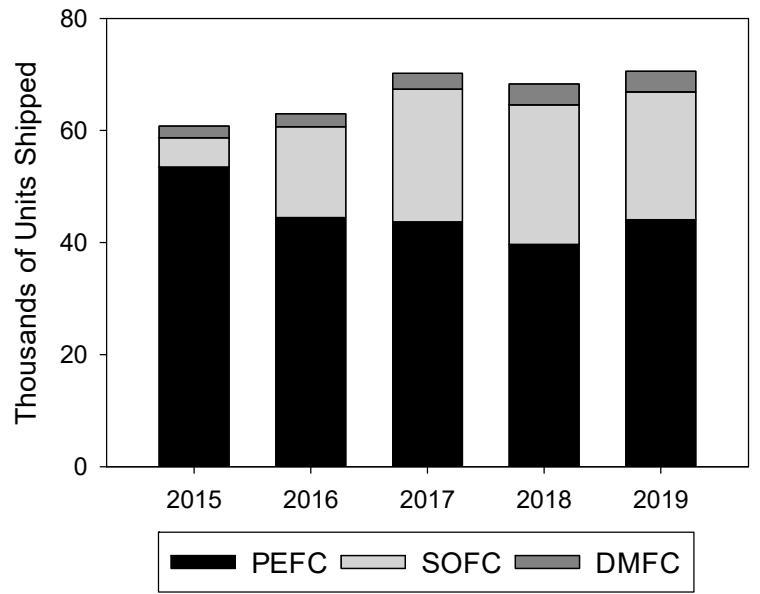

(b)

Figure 1. Fuel cell units shipped between 2015 and 2019 (2019 includes a partial forecast) by (a) application and (b) fuel cell type reproduced from [12].

Polymer electrolyte fuel cell (PEFC) technology is increasingly being adopted in the transport sector in fuel cell/hybridised vehicles including forklifts, buses, boats, trams, trains, drones, motorcycles, submarines and automobiles such as the Toyota Mirai or Hyundai ix35 [14-19], and even aircraft. PEFCs are the most widely adopted fuel cell technology in terms of units shipped over the last five years as seen in Figure 1b [12]. Of the 68,500 units shipped in $2018,58 \%$ were PEFCs, $36 \%$ were SOFCs, $5.4 \%$ were DMFCs and the rest PAFCs.

SOFC technology is less mature than that of PEFCs. The high SOFC operating temperature poses a significant difficulty, particularly surrounding material selection and design. SOFCs are available in several geometries, planar, tubular, and mixed types. Tubular cells are subdivided by size, regular tubular SOFCs and $\mu \mathrm{T}-\mathrm{SOFC}$. $\mu \mathrm{T}-\mathrm{SOFC}$ is a rather broad definition and typically means cells with external diameters of $<10 \mathrm{~mm}$. Generally speaking, tubular SOFCs are favoured for portable applications due to their mechanically durable natures and rapid start-up capabilities, which are particularly prevalent at the micro-tubular scale [1,2]. Figure 2 shows a schematic of a tubular cell with the operating principle and an indication of the current direction in the axial and radial dimensions.

Planar SOFCs are typically restricted to stationary applications due to their superior power densities and bulky/heavy system designs. Tubular SOFC technology is less mature than planar geometry as the higher demand for stationary power seen in Figure 1a has driven the development. However, the ever-increasing demand for power-hungry portable devices presents an opportunity for $\mu \mathrm{T}$-SOFC technology. As such, research and development into SOFCs, and specifically $\mu \mathrm{T}$-SOFC technology, must address key bottlenecks to be competitive. The key areas for development in SOFCs are material development [20-25], current collection/interconnection, sealing [26,27] and stack/system design [28-30]. Tubular SOFC current collection/interconnection development is somewhat more geometry-specific than the other aforementioned bottlenecks versus planar designs and thus is the focus of this study. The current collector design can have a significant effect on the performance and durability of a tubular cell [5]. Loose connections lead to unstable cell performance and ultimately cell failure. Current collector designs must be secure enough to withstand impacts incurred during portable applications. $\mu \mathrm{T}-\mathrm{SOFC}$ 
current collectors cannot simply rely on the compressive load for adherence and control over contact resistance as used in planar devices and additional effort into contacting must be made. This study will explore current collector materials, design, configuration and cell-specific design considerations. Emphasis is placed on the progression of current collector designs in order to quantitatively analyse and identify the most viable current collectors for delivering widespread $\mu \mathrm{T}-\mathrm{SOFC}$ commercialisation. A schematic of the key areas for development in micro-tubular SOFC technology and a breakdown of the current collector/interconnection specific topics covered in this study can be seen in Figure 3.

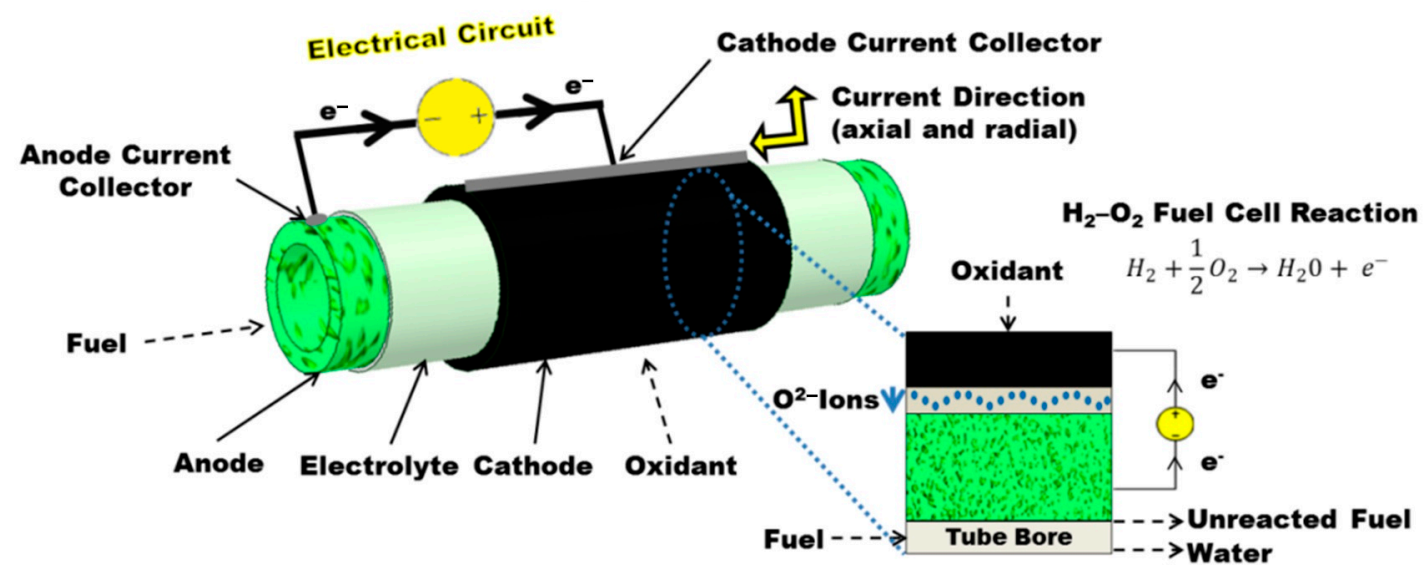

Figure 2. Tubular solid oxide fuel cell schematic with cross-sectional view, operating principle and current direction.

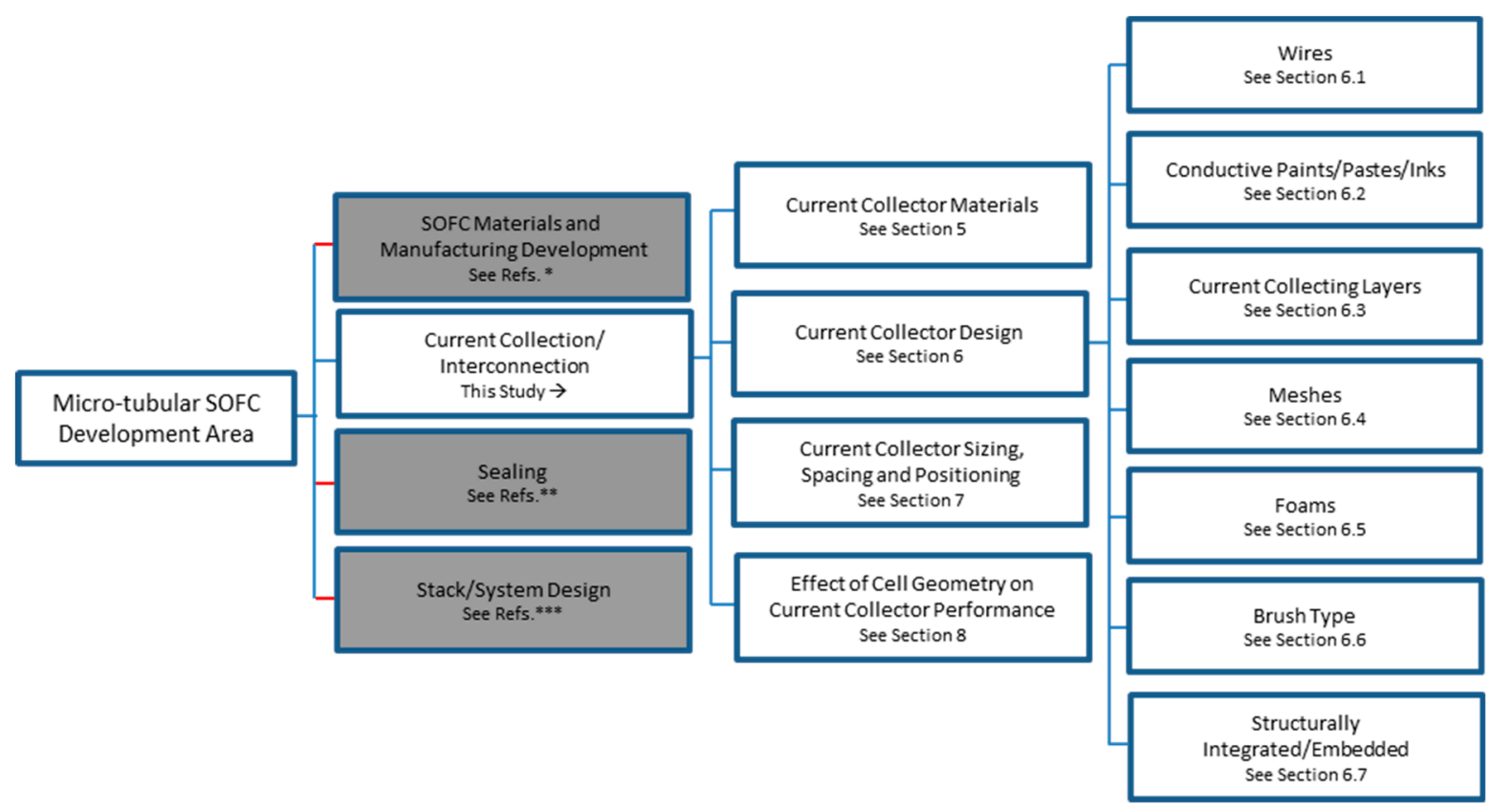

Figure 3. Key areas of development in micro-tubular solid oxide fuel cell (SOFC) technology and breakdown of current collection/interconnection topics covered in this review. References * $([20-25]),{ }^{* *}([26,27]),{ }^{* * *}([28-30])$.

\section{Tubular Solid Oxide Fuel Cells}

Solid oxide fuel cells operate at high temperatures between 650 and $850{ }^{\circ} \mathrm{C}$ and exhibit typical electrical efficiencies between 50 and $60 \%$, which is high when compared to other common fuel cells. If the heat generated by the SOFC is deemed useful, a combined heat and power (CHP) efficiency can be claimed at around and above $80-85 \%$. The "high quality" heat lends itself to integration into highly efficient steam and gas turbine power production systems [31]. 
Cells can either be self-supporting or externally supported. In the former, the electrode or electrolyte provides mechanical support for the cell [32]. In the latter, an external inert support may be used such as a porous ceramic material or the interconnect itself. Early tubular and planar cells were either cathode or electrolyte-supported but now the standard is anode-supported which allows for lower operating temperatures and ohmic polarisation, coupled with improved mechanical stability. Relying on the relatively more conductive anode as a support also comes with issues surrounding mass transport losses through the porous structure, the potential for reoxidation and loss of mechanical integrity and performance during operation. Externally supported cells are increasingly common in planar SOFCs, relying on the interconnect, typically a metal, or an inert ceramic for mechanical support. A schematic of tubular SOFC cell support configurations (which is also applicable to planar geometries) and the progression of the state of the art are seen in Figure 4.

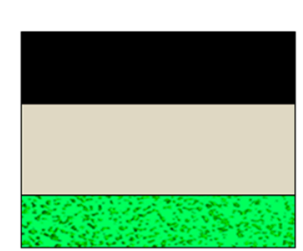

Electrolyte Supported

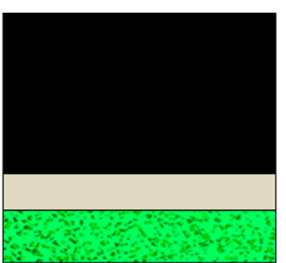

Cathode Supported

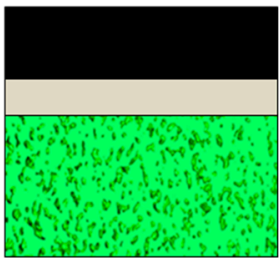

Anode Supported

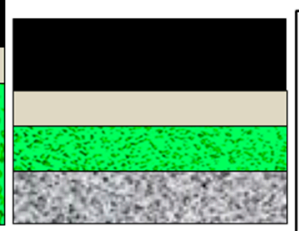

Externally Supported
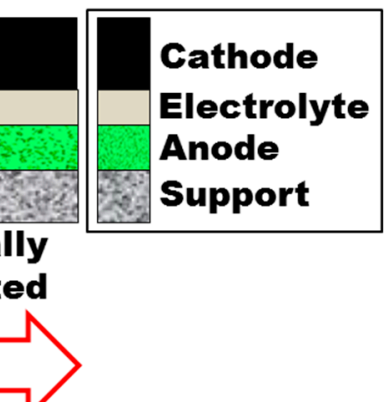

Figure 4. Tubular (and planar) SOFC cell support configurations and the progression of the state of the art.

The trend of SOFCs towards a lower operating temperature has widened the material selection for SOFC components [33]. Metal-supported planar cells have lower thermal masses and are less brittle than a ceramic-supported cell and so can handle faster start-up times [34]. However, the operation is typically limited to lower temperatures $\left(550\right.$ to $\left.650{ }^{\circ} \mathrm{C}\right)$ to avoid rapid degradation of the metallic components which restricts the use of internal reforming of hydrocarbons, typically occurring above $650{ }^{\circ} \mathrm{C}$. In tubular devices, porous inert supports such as ceramics and metallic supports have been used. This allows for a segmented tubular cell design, essentially stacking cells along a support similar to integrated planar designs $[35,36]$. The externally supported SOFCs allow thinner electrode layers and electrolytes, incurring lower ohmic and mass transport losses. Similarly to planar interconnects, tubular supports can contribute to controlling gas flow to improve fuel utilisation. If electrically conductive, the support can also contribute to the current collection.

Regular tubular were the first tubular SOFC, developed by Siemens Westinghouse, having a typical diameter of 1" and $2200 \mathrm{~mm}$ length [37]. Micro-tubular SOFCs developed by Kendall in the early 1990s had diameters in the order of a few millimetres and a length one or two orders of magnitude shorter than their larger predecessor [38]. The inverse proportionality of power density with tube radius means smaller cells have higher power densities [39]. More recently, tubular SOFC cells have been reported with larger diameters in the order of a few centimetres giving a higher total power per cell. This reduces the number of cells required in a stack for a given power output which again reduces complexity in manufacturing and assembling. Nevertheless, the larger size brings less mechanical stability.

The distinguishing characteristics of planar versus micro-tubular SOFCs are seen in Table 1. Micro-tubular fuel cells have inherently facile sealing and gas flow control, given that the dense electrolyte separates gas streams rather than an interconnect. Tubular fuel cell designs exhibit similar power densities to planar devices at up to $1.5 \mathrm{~W} \cdot \mathrm{cm}^{-2}[40,41]$. The $\mu$ T-SOFC concept lends itself to high mechanical strength and high thermomechanical 
durability. This strength is inversely proportional to cell diameter. The durability to mechanical shock and thermal cycling of $\mu \mathrm{T}$-SOFC allows for rapid start-up times in the order of a few seconds [1]. The aforementioned enables near-instant on-demand power, permitting $\mu \mathrm{T}$-SOFCs to be used for both stationary and portable power applications [42] This widens the market for SOFC technology not typically accessible by planar devices. Several commercial companies have worked on $\mu \mathrm{T}$-SOFC development including Adelan, Acumentrics, AMI, Ezelleron, Protonex, Komico, NGK, Toto, Tokyo Gas and others [38,43]. Tubular SOFC products have reached the commercial market globally, most widely adopted in Japan and Korea [44]. Portable devices have included the tubular Kraftwerk [45], a 5 V (10 W peak power) charging device (which was eventually never produced).

Table 1. Characteristics of micro-tubular ( $\mu \mathrm{T})$-SOFC and planar SOFC.

\begin{tabular}{ccc}
\hline Characteristic & Microtubular & Planar \\
\hline Power Density & Medium & High \\
Mechanical Strength & High & Lower \\
Start-up & Fast & Slower \\
Interconnect & Difficult/Cumbersome & Straightforward \\
Sealing & Facile & Complex \\
Manifold & Simple & Simple \\
Stack Power Density & Medium & High \\
System Compactness & High & High \\
Manufacturing Cost & Medium-High & Lower \\
\hline
\end{tabular}

The number of journal and conference articles in the academic literature on tubular SOFCs has followed a declining trend over the past five years, as seen in Figure 5a. Instead, research has widened into more fundamental problems associated with $\mu \mathrm{T}-\mathrm{SOFC}$ (and in most cases planar SOFCs), such as sealing, manifolding and material development. Research in the field has been dominated by authors from China, showing nearly double the number of studies as from the USA which is the next largest contributor, as seen in Figure $5 \mathrm{~b}$. Material development and testing, which are common SOFC development areas, are easier to conduct in planar form. Interconnection/current collection in tubular SOFCs is a critical area for development and remains a bottleneck in the commercialisation of tubular cells and stacks. The focus of $\mu \mathrm{T}-\mathrm{SOFC}$ current collection in this review aims to identify what has been achieved to date in order to identify the most viable current collection design(s) for the future and highlight future challenges.

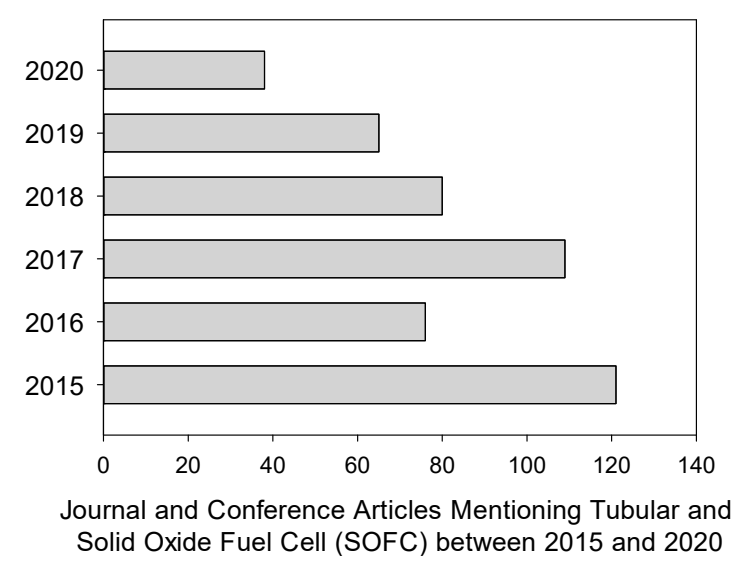

(a)

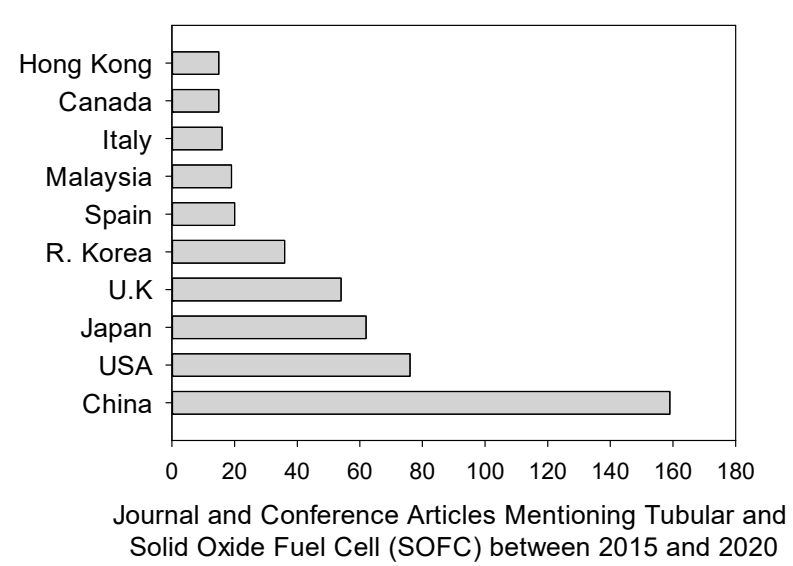

(b)

Figure 5. Number of journal and conference articles between 2015 and 2020 mentioning tubular and solid oxide fuel cells (SOFCs) from an Engineering Village search (a) by year and (b) by location. 


\section{Current Collection in $\mu \mathrm{T}-\mathrm{SOFCs}$}

To extract power from a tubular SOFC cell, current collectors must be used at each electrode. The low voltage characteristic of a fuel cell means cells are typically stacked to achieve a useful power output by interconnecting current collectors of adjacent cells in series. Current collection in tubular SOFCs is complex and is particularly tricky at the $\mu \mathrm{T}$ SOFC scale. Minimising current conduction pathways and thus minimising the resistance to electron flow is critical in reducing the ohmic resistance of interconnections [4,5]. In planar configurations, the interconnect is in-plane with the electrodes of repeating cell units, contacting a large area of the electrochemically active region, resulting in short, mostly out-of-plane electron conduction pathways [6]. In tubular configurations, however, cells are spaced apart. The minimum limit for cell spacing which is controlled by the manifold design is determined as a function of assembly logistics, wiring logistics and by the thermal management and gas supply design. These restrictions limit compactness, resulting in an interconnection network with a considerably higher pathway length, as compared to the planar configuration. The cylindrical geometry plays a factor in the complexity, as current flows in the axial and radial dimensions (seen in Figure 2), increasing current conduction pathway length and leading to complexity in the interconnect design [46]. The direction of the current flow within each cell and throughout a stack can vary greatly with the current collector/interconnect configuration.

The early micro-tubular cells of the 1990s, developed by Kendall and Kilbride from Keele University (UK), had "internal" anode current collection, typically nickel or silver, either as a spring-loaded coil or as a rolled mesh inserted within the cell (on the bore side in the fuel channel). Cathode current collection was typically achieved via silver wire wrapped/wound around the cell "exterior" [47-50]. Anode current collection changed direction somewhat in the 2000s when research from AIST (Japan), such as Suzuki [51,52] and Dhir and K. Kendall (GB) [53-55], developed a technique to contact the anode from the cell exterior (external anode current collection) by either partially covering the anode support with electrolyte during fabrication, or by moving a portion of electrolyte to expose the anode interior (of an anode-supported cell). A schematic of internal and external current collections of an anode-supported tubular SOFC is shown in Figure 6.

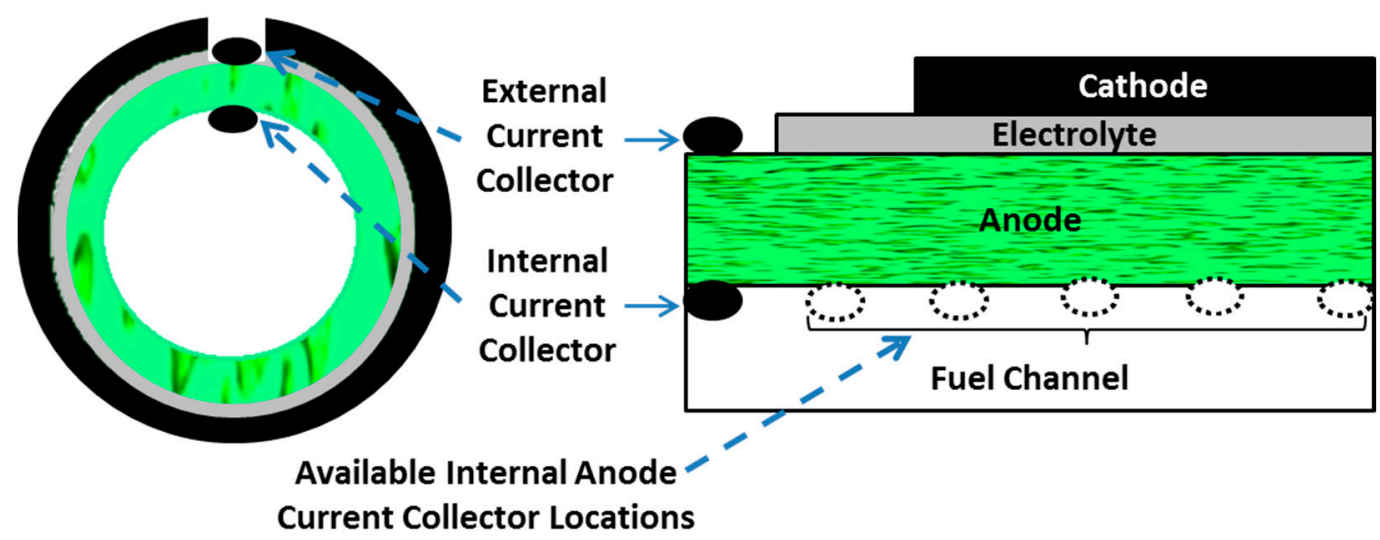

Figure 6. Cross-sectional schematic of internal and external current collection in an anode-supported $\mu \mathrm{T}-\mathrm{SOFC}$ with available internal anode current collector locations (not to scale).

Results from the latter researchers showed that loss of contact between internal current collectors and the electrode due to thermal mismatch/shrinking and improper contacting led so severe degradation, indicating that $R \& D$ into a method for interconnect-electrode contacting for internal current collector designs was needed. The externally contacted anode showed enhanced electrochemical stability when tested and a reduced degradation rate. However, the new style necessitated sealing of the porous, exposed anode with hightemperature gas-tight sealants, another key area of development in SOFC technology [56]. Accessing the anode from the cell exterior leads to a loss of external cell surface which could 
be otherwise used for current production. However, using an internal current collector does not incur such penalties and thus the entire cell exterior can be utilised as indicated by the available internal anode current collector locations seen in Figure 6. Therefore, for a given cell length, using an internal current collector leads to a higher total power output potential from a cell. The method used for the current collection from the cathode of anode-supported cells has remained largely unchanged from the aforementioned research conducted in the early 1990s - specifically, wrapping or hatching wire (most often silver) around the cathode surface, bound either using mechanical force or by using adhesive pastes/sealing materials, which are typically silver-, gold- or platinum-based.

\section{Current Collector Performance}

Fundamentally, an SOFC interconnect must have a low ohmic resistance to minimise ohmic polarisation and thus must have a high electrical conductivity (bulk) and a low contact resistance. The resistance to electron flow or ion flow is governed by Ohm's law, from which we observe the proportional nature of voltage drop with current and resistance. The Area-Specific Resistance (ASR) is the key metric used to determine the ohmic resistance of a cell. This normalised metric allows for comparison of different sized cells on an equivalent basis. The ASR of a cell can be derived from experimental data as an average over a potential range within the linear ohmic region from the gradient of the polarisation curve (Equation (1)):

$$
\operatorname{ASR}\left[\Omega \cdot \mathrm{cm}^{2}\right]=\frac{\eta_{\text {ohmic }}[\mathrm{V}]}{\Delta i\left[\mathrm{~A} \cdot \mathrm{cm}^{-2}\right]}
$$

where the potential range should be the ohmic overpotential $\eta_{\text {ohmic }}[\mathrm{V}]$, taken over the linear ohmic loss dominated region of the $\mathrm{i}-\mathrm{V}$ curve and $\Delta i$ is the current density difference over that range. The ASR can also be measured locally at a given potential or current by electrochemical impedance spectroscopy (EIS), where the total resistance $R_{T}$ is measured and then adjusted by the active area (Equation (2)) [57]:

$$
\text { ASR }\left[\Omega \cdot \mathrm{cm}^{2}\right]=A_{\text {cell }}\left[\mathrm{cm}^{2}\right] * R_{T}[\Omega]
$$

It should be noted that the ASR calculated in Equations (1) and (2) are for the entire cell, and so the contribution from activation and mass transport polarisation is present, even though the data acquisition conditions are set so that the ohmic effects dominate the results. However, the ohmic polarisation, $R_{\Sigma \Omega}[\Omega]$, which is cell-specific, can be directly acquired from EIS data, yet still contains a contribution from ionic flow resistance in the electrolyte and electron flow in the electrodes and interconnect. However, adjusting this value by the cell area does not give the ASR. The ASR of a virgin or tested material can be calculated ex situ by measuring the resistivity, $\rho$, of known material thickness, Equation (3) [6]:

$$
\operatorname{ASR}\left[\Omega \cdot \mathrm{cm}^{2}\right]=x[\mathrm{~m}] * \rho[\Omega \cdot \mathrm{cm}]
$$

ASR targets for interconnect materials of the past (pre-2000s) were $<100 \mathrm{~m} \Omega \cdot \mathrm{cm}^{2}$. With the more recent advancements in $R \& D$, this target has been lowered by an order of magnitude within the last five years to $<10 \mathrm{~m} \Omega \cdot \mathrm{cm}^{2}[22,58,59]$. The target for overall cell resistance is $<500 \mathrm{~m} \Omega$ with $<1 \Omega$ deemed to be acceptable. The typical contribution of an SOFC interconnect to the ohmic polarisation is around 20 to $25 \%$. The ohmic resistance of the interconnect itself can be broken down into contributions from the bulk material conductivity (which is the inverse of the resistivity), Equation (4), and the contact resistance. Targets for values of the contact resistance are between 0.01 and $0.05 \Omega \cdot \mathrm{cm}^{2}$ [60].

$$
\sigma\left[\mathrm{S} \cdot \mathrm{m}^{-1}\right]=\frac{l}{R A}
$$


The three major factors related to interconnect contact resistance are (a) dimension tolerance and flatness of the interconnect, (b) nonuniform compression from the interconnect on to the electrode and (c) the state of the contact surface (roughness, spallation, defects). While optimising the cell materials for low resistance is important, it is common to test the performance of the material within a cell, which will better account for the real-world tolerances in contacting, hence the use of the cell ASR as a common metric in comparisons.

\section{Materials for Current Collection}

Given the intimate connection of an interconnect to adjacent cell components, its material must have a similar thermal conductivity and thermal expansion coefficient to adjacent cell components and be chemically compatible in reducing and oxidative (RedOx) environments. Mechanical integrity and low weight must also be considered, particularly for portable applications, in addition to low cost and ease of manufacture/assembly [6,22]. In tubular configurations, the interconnect does not always act as a barrier between the opposing anode and cathode environments, depending on the cell design. This opens up some degrees of freedom on interconnect requirements, and designs can be tailored to a specific electrode. Specifically, the requirement for gas-tightness and stability in both RedOx environments, when dropped, can widen the suitability of materials and interconnect design choices.

\subsection{Historical Trend in SOFC Interconnect Materials}

The trend in interconnect material selection, following the movement from hightemperature SOFC operation above $850{ }^{\circ} \mathrm{C}$ to lower temperatures around 700 to $750{ }^{\circ} \mathrm{C}$, has replaced the traditionally used ceramic perovskite-type materials such as $\mathrm{LaCrO}_{3}$, as used in the original Westinghouse tubular designs, by nickel- or chromium-based steels and more recently ferritic stainless steels, as seen in Figure 7 [6,61]. Ceramic-based interconnects are brittle, costly and bring difficulties concerning their manufacture, shaping and cell assembly [62]. Metallic interconnects, however, are less brittle, potentially lower in cost, and possess inherent ductility, lending themselves to facile shaping. Metallic interconnects also have a much higher thermal conductivity than the traditional ceramic counterparts which leads to a favourable reduction in start-up/shut-down times of stacks, widening the scope for potential SOFC applications [6]. Typical metallic interconnect materials include ferritic stainless steels such as Crofer 22A/APU/H and ITM, chromium-based materials such as CFY [63], austenitic steels such as Alloy 310 [64] and nickel-based alloys such as Haynes 230, favoured for its corrosion resistance over Inconel and Hastelloy counterparts [65-67].

Trends of $R \& D$ of SOFC Interconnect Material

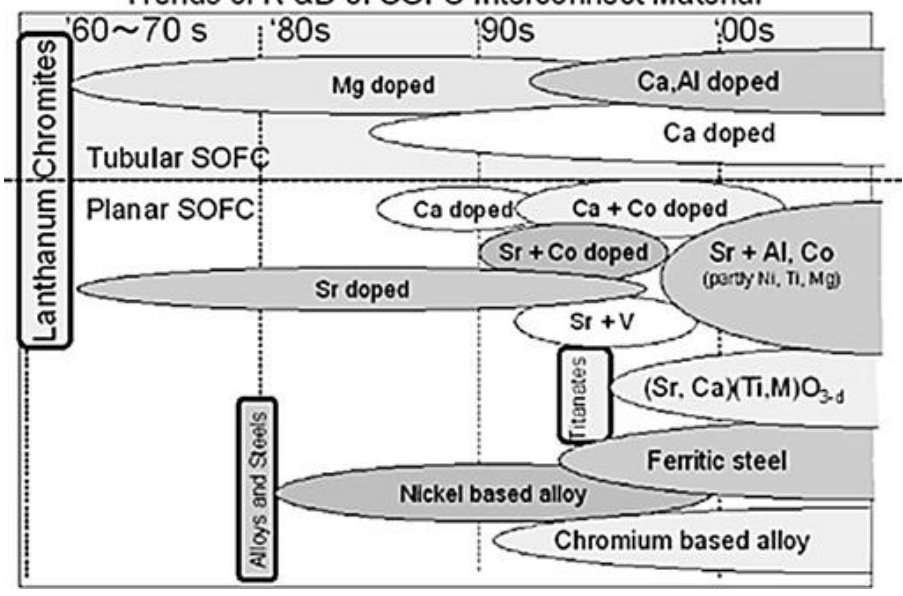

Figure 7. Trend in R\&D of SOFC interconnect materials [68]. 


\subsection{Metallic Interconnects}

Metallic interconnects come with their own problems, namely the increase in ASR and decrease in mechanical properties resulting from reactivity in redox environments through high-temperature corrosion mechanisms, as seen in Figure 8 [69-71]. It should be noted that the ASR values of a current collector material are not the same as the ASR values of a cell using this material as a current collector. The ASR of a cell will be significantly higher given the additional contribution of the electrodes and electrolyte. The ASR of a material has a contribution from the bulk conductivity and the surface contact resistance, the resistance at the interface of that material with the measuring device/adjacent materials. Chromium is typically used as an alloying element in metal interconnects to adjust the coefficient of thermal expansion (CTE) to fuel cell electrodes and the electrolyte. The chromium content is also important as it serves as a reservoir for the formation of a protective coating to prevent further oxidation. For an SOFC interconnect the ideal chromium range is between 18 and $22 \mathrm{wt} \%$, above which it contributes considerably to the ohmic resistance and below which it will not form the protective coating. Volatile chromium species migrate to the cathode which causes poisoning [72]. Nevertheless, protective barrier layers can be applied to the exterior surface of the interconnect to minimise these effects. Studies to mitigate such degradation have focused on optimisation of the composition and application techniques of the protective coatings such as $(\mathrm{Mn}, \mathrm{Co})_{3} \mathrm{O}_{4}$ and the control of naturally formed oxide layer growth, particularly in stainless steels [58,73-75].

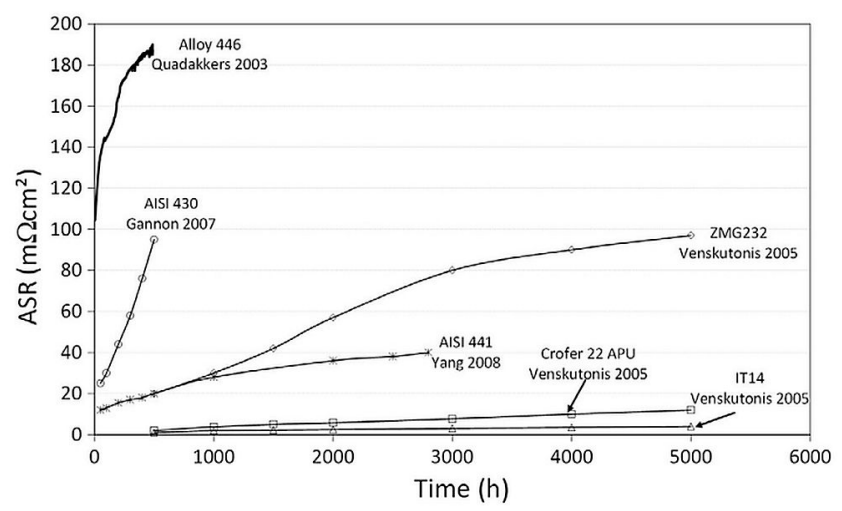

Figure 8. Area-Specific Resistance (ASR) evolution of typical interconnect materials over exposure time [6].

A key advantage of metallic current collectors is the ability to be joined to the electrodes, with other current collectors (interconnection), and to stack components with standard welding or brazing techniques [59,76]. A compressive load is applied to a planar stack to ensure intimate contact between fuel cell and interconnect components which is not possible in a tubular configuration, further highlighting the need for secure interconnectelectrode and interconnect-interconnect joints able to withstand the thermally induced stresses and mechanical impacts incurred during operation [77]. Welding and brazing both use heat to melt a filler material that joins parent materials together. Welding is limited to metals and requires a higher temperature than brazing as the parent metal must also melt. Welding is suitable for exterior joints or where localised hot spots caused by the welding flame are not an issue. Welded joints often have very high strengths and can be fabricated at scale at a low cost. Brazing can be achieved at far lower temperatures than welding and both metals and nonmetals, such as ceramics, can be brazed as only the filler material melts. Brazing can be performed by induction, whereby a current passes through a magnetic metal braze causing it to flow and form a joint once cooled. Brazing can also be performed in a furnace with a flame or electrical heating. The furnace can be used to carefully control the heating/cooling rate of the parent and braze materials which can alleviate CTE mismatches between components and avoid the formation of mechanical stress and failure in fuel cell components such as the electrolyte. 
Gas tightness is an imperative interconnect property when acting as a barrier between opposing chemical environments as any leakage would lead to fuel combustion, fuel which will not be converted to electrons, leading to thermal hot spots which accelerate local degradation [78].

\subsection{Micro-Tubular SOFC Geometry-Specific Current Collector Material Trend}

In tubular configurations, solely the electrolyte provides the barrier between the fuel and oxidant atmospheres, giving an additional degree of freedom to interconnect material choice, potentially tailoring to suit either the anode or cathode side. This, combined with the lack of requirement for load-bearing/compressive strain, has led to the use of highly conductive but costly precious metals, the most common being silver, followed by platinum, gold and palladium. These precious metals are known for their inertness and stability in high-temperature redox environments and do not form nonconductive oxide layers in air at elevated temperatures. Nickel, a nonprecious, favourably low-cost but relatively less conductive metal, is also frequently used as seen in Figure 9.

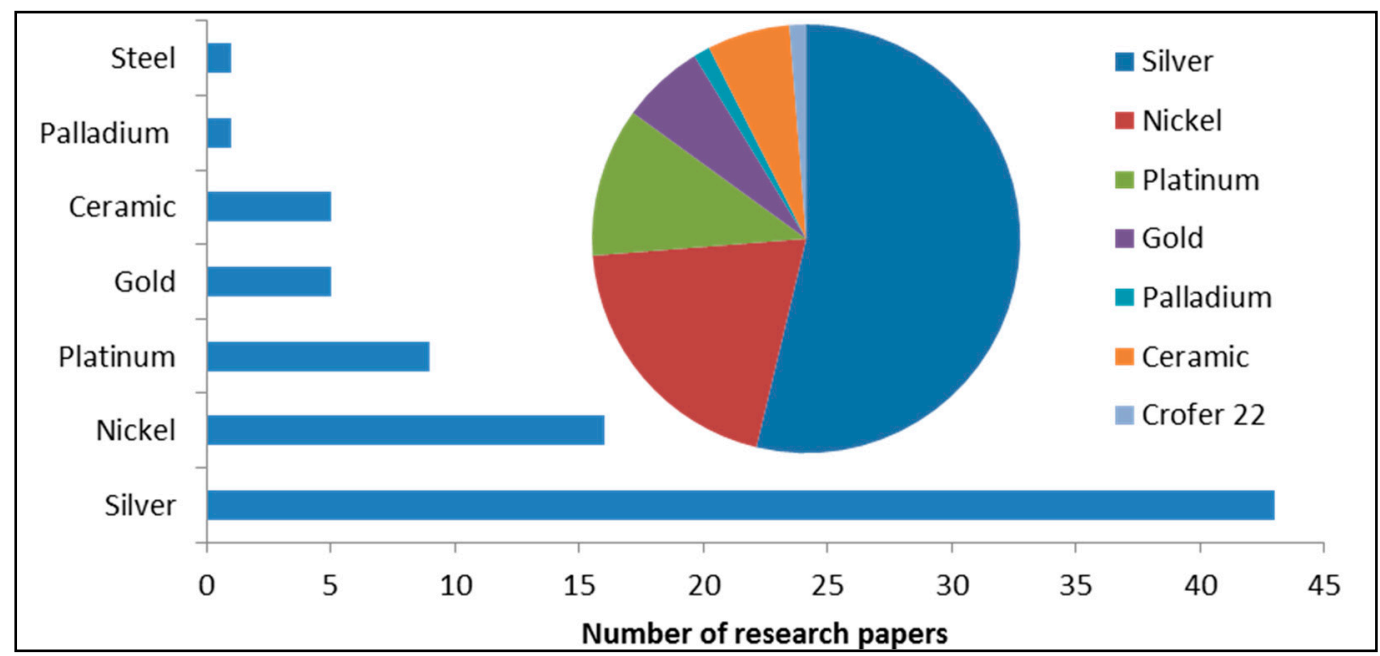

Figure 9. Current collector materials used in $\mu$ T-SOFC tests reported in literature between 2015 and 2020.

While most frequently used, silver is not without fault. Compson et al. [79] suggested using silver as an SOFC interconnect at temperatures below $650{ }^{\circ} \mathrm{C}$ to avoid loss of silver via sublimation, evaporation and diffusion. Degradation is particularly prevalent in silver under a dual atmosphere (redox) which may occur if silver is being used as a conductive paste on an externally accessed anode current collector or around fuel manifolds. Oxygen and hydrogen permeate the structure and form steam bubbles, leading to cavity nucleation and growth, and henceforth a loss of hermeticity [80]. Majewski et al. [81] observed the degradation of silver in a redox environment within $8 \mathrm{~h}$ of operation when used as a $\mu$ T-SOFC current collector at $700{ }^{\circ} \mathrm{C}$. They observed temperatures $100{ }^{\circ} \mathrm{C}$ above the furnace temperature at the interface, indicating fuel crossover and resulting (spontaneous) combustion due to porosification of the originally gas-tight/dense silver sealant. Any silver migration could also lead to short-circuiting and reduced performance. While the melting temperature of silver is $961^{\circ} \mathrm{C}$, higher than typical SOFC operating temperatures, softening (annealing) of the wire and hence the loss of mechanical integrity occurs at far lower temperatures, a key factor for loss of interconnect-anode contact of silver-based internal current collectors [82]. Ding et al. [83] attributed the failure of their four-cell stack to severed silver wires after only $4 \mathrm{~h}$ of operation at $800^{\circ} \mathrm{C}$ and stated an urgency in finding an alternative current collector material for their tubular cells.

While nickel is somewhat stable in reducing environments, it undergoes high-temperature corrosion in oxidising environments, causing the formation of nonconductive oxide layers, hence its use on the anode side only (unless coated). Stable as it may be in reducing envi- 
ronments, nickel is a well-known reforming catalyst, which is employed in Ni-YSZ anodes for the electrochemical oxidation of hydrogen and in direct internal reforming. When used as an anode side interconnect with hydrocarbon fuels, there will likely be a reduction in performance of the interconnect over time from carbon formation [84]. The metallic structure, high melting point and thermo-mechanical integrity of nickel across SOFC operating conditions favour it as an affinitive base metal to support well-adhered protective coatings. Coating with a more inert/corrosion resistant, more electrically conductive and hard/hard wearing natured materials such as gold, silver, nickel alloys and even perovskites can enhance the electrical performance and durability of nickel as a current collector for both the anode and cathode. Coatings can be achieved by simple painting/dipping techniques, by electroplating, a current-driven process, or by electroless plating, a chemically driven process, of which the latter two can be produced at scale. Electroless plating achieves a more homogenous coating and finer control over layer thickness (proportional to exposure time for a given plating chemistry) than electroplating, particularly for intricate parts of differing thicknesses where an applied potential results in varying current densities, and thus differing rates of localised coating application [85-87].

A study by Hatchwell, Sammes and Kendall [47] looked at cathode side current collection methods from a materials perspective. The experiment determined whether a perovskite-coated nickel-based steel (Nimonic 90) could show comparable performance to the more commonly used silver wire. The coating suppressed chromium migration, but the electrical performance could not match that of the silver wires. They further discussed the limitations of using silver due to its high evaporation rates at typical SOFC operating temperatures, meaning unpredicted temperature spikes could inflict irreparable damage to the silver. Wire and strips of the silver were very close in performance, while a comparison of silver conductive ink covering the entire cathode versus a two-strip configuration suggested the ink interference in cathode performance was negligible for this ink composition and cell geometry. The properties of typical SOFC interconnect materials are given Table 2 .

Table 2. Material properties of commonly used SOFC interconnect materials. Typical anode material, Ni-YSZ included for reference.

\begin{tabular}{|c|c|c|c|c|c|}
\hline Material & $\begin{array}{c}\mathrm{CTE} \\
\times 10^{-6}[\mathrm{~K}]\end{array}$ & $\begin{array}{l}\text { Conductivity } \\
{\left[{\mathrm{S} . \mathrm{cm}^{-1}}^{-1}\right.}\end{array}$ & $\begin{array}{l}\text { Melting Point } \\
{\left[{ }^{\circ} \mathrm{C}\right]}\end{array}$ & $\begin{array}{c}\text { Young's Modulus } \\
\text { [GPa] }\end{array}$ & $\operatorname{Ref}(s)$ \\
\hline Ni-YSZ & $11-13$ & $3 \times 10^{2}\left(800^{\circ} \mathrm{C}\right)$ & - & $57-58\left(800^{\circ} \mathrm{C}\right)$ & {$[6,20,88]$} \\
\hline $\mathrm{LaCrO}_{3}$ & 9.5 & $0.34\left(700^{\circ} \mathrm{C}\right)$ & 2510 & - & {$[20,24,77]$} \\
\hline Crofer 22-APU (ferritic) & $11.5-12.5$ & $\begin{array}{l}8.3 \times 10^{4}\left(1000^{\circ} \mathrm{C}\right) \\
8.7 \times 10^{3}\left(800^{\circ} \mathrm{C}\right)\end{array}$ & $1510-1530$ & $216\left(750{ }^{\circ} \mathrm{C}\right)$ & [88-91] \\
\hline Haynes 23 (nickel-based) & $15.2\left(800^{\circ} \mathrm{C}\right)$ & $7.7 \times 10^{3}\left(800^{\circ} \mathrm{C}\right)$ & $1301-1371$ & $159\left(800^{\circ} \mathrm{C}\right)$ & {$[67,92]$} \\
\hline $\begin{array}{l}\text { Ducrolloy } \\
\text { (Cr-based) }\end{array}$ & $11.8-12\left(800^{\circ} \mathrm{C}\right)$ & $1 \times 10^{4}\left(1000^{\circ} \mathrm{C}\right)$ & 1700 & - & {$[93,94]$} \\
\hline Silver $(99.9 \%)$ & $18.9,22\left(800^{\circ} \mathrm{C}\right)$ & $1.6 \times 10^{5}\left(800^{\circ} \mathrm{C}\right)$ & 961 & $69-74\left(800^{\circ} \mathrm{C}\right)$ & {$[24,95,96]$} \\
\hline Nickel & $12-13.5\left(800{ }^{\circ} \mathrm{C}\right)$ & $2.5 \times 10^{4}\left(800^{\circ} \mathrm{C}\right)$ & 1455 & $190-220\left(800^{\circ} \mathrm{C}\right)$ & [97] \\
\hline Platinum & $10\left(800^{\circ} \mathrm{C}\right)$ & $2.3 \times 10^{4}\left(800^{\circ} \mathrm{C}\right)$ & 1769 & $127\left(800^{\circ} \mathrm{C}\right)$ & {$[24,98]$} \\
\hline Gold & $16.6\left(800^{\circ} \mathrm{C}\right)$ & $1.1 \times 10^{5}\left(800^{\circ} \mathrm{C}\right)$ & 1064 & $76-81\left(800^{\circ} \mathrm{C}\right)$ & {$[24,99]$} \\
\hline Palladium & $12.3\left(800^{\circ} \mathrm{C}\right)$ & $2.55 \times 10^{4}\left(800^{\circ} \mathrm{C}\right)$ & 1552 & $118-124\left(800^{\circ} \mathrm{C}\right)$ & {$[24,100]$} \\
\hline
\end{tabular}

\section{Current Collector Shape and Structure}

Once the designer has chosen the optimal interconnect material, the thickness, shape and structure must be determined. For a planar device, this will be some sort of flat plate with an optimised corrugation/patterning for fuel and exhaust flow. In a tubular device, the decision is less clear and depends on whether current is collected on the bore side of the tube or the outer surface. The material will need to be formed to achieve intimate contact with the electrode and so a format that can be easily worked/shaped is preferable. The need to minimise the electron pathway and maximise the contact area for current collection 
means designs can vary greatly. A study in planar SOFCs by Jiang et al. [101] showed that when current collector-electrode contact area was increased from $4.6 \%$ coverage to $27.2 \%$ the resistance of the cell decreased by $87 \%$ from $1.43 \Omega \cdot \mathrm{cm}^{2}$ to $0.19 \Omega \cdot \mathrm{cm}^{2}$ at $800{ }^{\circ} \mathrm{C}$. Consideration to preventing the current collector from impeding gas flow to and from the electrode must also be made remembering that an impermeable/nonporous current collector covering the entire electrode surface would render the fuel cell useless. The tube dimension is a key factor in the design and problems can be common or specific to small/large bore and short/long variants. For example, in small-bore tubes (less than 2 to $3 \mathrm{~mm}$ ID), internal access is particularly difficult and the current collector size is limited, limiting the size and wire thickness and thus its current-carrying ability (with respect to voltage loss), which is exacerbated if the length of the cell and contact wires are long. For larger bore tubes, achieving a suitable spring force (arising from the elasticity of the contacting material), which is often relied on for smaller bores, becomes difficult due to the softening of the material at an operating temperature which has a more significant impact on larger structures than smaller.

\subsection{Wires}

Wires are the most common choice for current collection and are used in some form in all but three of the publications reported in the literature between 2015 and 2020, whether used for the anode and/or cathode current collection, as measurement probes, as the sole current collector, or in a combination with another design. In the last 5 years, the most common wire choice has been silver, followed by platinum, then gold and nickel. Wires are readily available in most materials and dimensions and when chosen correctly achieve highly efficient current collection/conduction over long distances, thus constituting an ideal candidate for interconnection between adjacent cells. Wires were the first $\mu$ T-SOFC current collectors to be used, published in the academic literature of the late 1990s $[47,48,102]$. Wires can be easily formed and shaped and can come in different profiles including round, flattened and triangular, which can vary the available contact area, fitting and mechanical properties of the wire. Increasing the diameter of the wire reduces the voltage loss in the wire for a given current. Braiding is useful when the correct diameter of wire is not available and has the advantage of increasing the mechanical strength of the wire, important when a wire is operating at a temperature close to its softening/melting point. Wires can be easily shaped and are often coiled to fit the interior and exterior of the tube. Wires can be joined to create crisscrossed mesh-like structures, or into strips and bands. The cell with the highest power density reported in the literature was recently published by Ren et al. [41], where silver wire and silver paste were used for both the anode and cathode sides of their alumina-supported "microchannel structured" cells. They achieved a current density of $1.4 \mathrm{~A} \cdot \mathrm{cm}^{-2}$ at $0.7 \mathrm{~V}$ and a peak power density of $1.5 \mathrm{~W} \cdot \mathrm{cm}^{-2}$ at $700{ }^{\circ} \mathrm{C}$ although the cell did not supply an open circuit voltage (OCV) of over $1 \mathrm{~V}$, which indicated either a severe fuel leakage and/or that the electrolyte was not complete and fully dense. When operated directly on methane, the peak power density was $1 \mathrm{~W} \cdot \mathrm{cm}^{-2}$ and the ASR determined by EIS at OCV was $0.32 \Omega \cdot \mathrm{cm}^{2}$ at $700{ }^{\circ} \mathrm{C}$.

Rabuni et al. [103] achieved a current density of $1.25 \mathrm{~A} \cdot \mathrm{cm}^{-2}$ at $0.7 \mathrm{~V}$ with a peak power density of $1.2 \mathrm{~W} \cdot \mathrm{cm}^{-2}$ and an OCV greater than $1.1 \mathrm{~V}$ at $750{ }^{\circ} \mathrm{C}$. The cell reached $1.8 \mathrm{~A} \cdot \mathrm{cm}^{-2}$ and $1.62 \mathrm{~W} \cdot \mathrm{cm}^{-2}$ when operating at $800{ }^{\circ} \mathrm{C}$. The ASR determined by EIS was approximately 1 and $1.26 \Omega \cdot \mathrm{cm}^{2}$ at 750 and $800{ }^{\circ} \mathrm{C}$, respectively. The authors used silver wire and silver paste for both anode and cathode current collection. The anode had six microchannels as well as an optimised microstructure with finger-like structures for enhanced mass transport, as seen in Figure 10. 

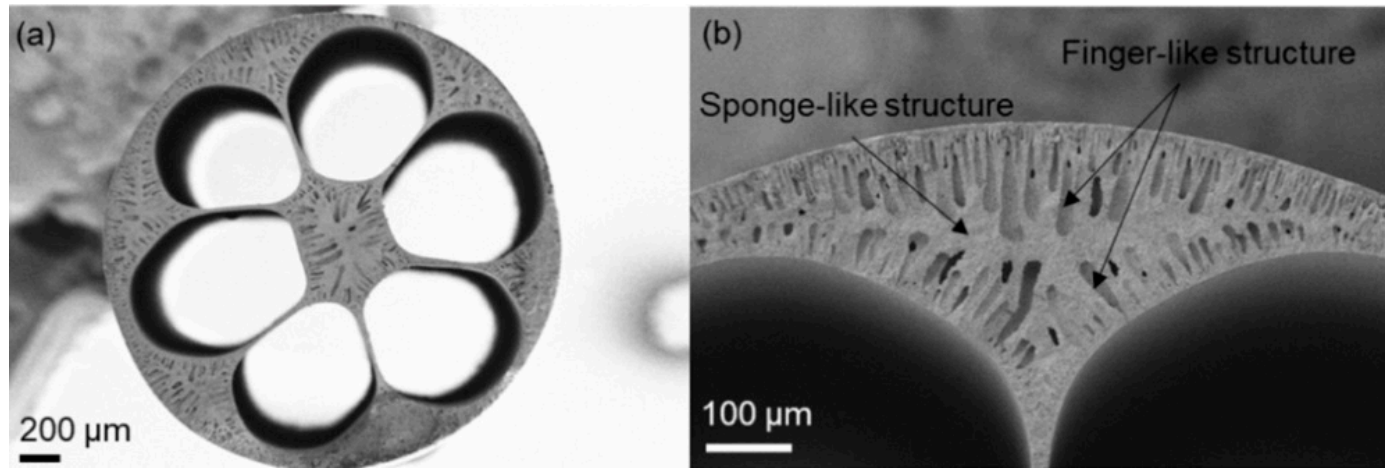

Figure 10. Cross-sections of a 6-channel $\mu \mathrm{T}$-SOFC cell with optimised microstructure [103] (a) overall cross-section, (b) zoom of micro-structure.

\subsection{Conductive Pastes, Paints and Inks}

Wires (and other current collector types) are seldom used on their own; they are often used with the addition of conductive metal-based pastes/paints/inks (from here on jointly referred to as "pastes"). The pastes can be applied to the electrode, to the current collector or to both [104]. The paste acts to decrease the interfacial contact resistance between the electrode and current collector and acts as a bridge to ensure a continuous path for electron flow. The pastes are more conductive than typical anode cermets and cathode materials and so the paste will increase the overall conductivity of the cell in the axial and radial directions, acting as a current collection layer, which is particularly important for larger cells $[105,106]$. Pastes can also be used to secure the electrode to the current collector and are sintered to enhance their mechanical adhesion once applied [107]. Pastes are usually hand-painted, which is a cause for concern in terms of w.r.t reproducibility and manufacturability [104].

The paste materials are most commonly silver, gold, platinum or nickel, the latter being reserved for the anode side $[108,109]$. Manufacturers sell variants with varying final porosity to control the gas distribution and conductive properties. Denser variants are favoured when the contact patch is small in order to maximise the conductivity of the joint, or where sealing is also required, meaning the paste has dual functionality. More porous paints, which are typically less viscous (generally referred to as paints or inks) can be spread more liberally, covering the entirety of the active area if desired, which may lend itself to ease in manufacturing [40]. The conductive pastes can also infiltrate the electrodes and improve electron mobility in percolation pathways. Silver's functionality as a cathode material, acting as a catalyst for oxygen reduction, will contribute to electrochemical cell performance [81].

\subsection{Current Collecting Layers}

Somewhat similar to conductive pastes, current collecting layers can be used to improve the overall conductivity of an electrochemical cell. They can be electrode or nonelectrode materials, with properties biased towards current conduction rather than electrochemical/catalytic activity. The layers are typically formed in situ during cell manufacture and can also provide mechanical support for the cell. Panthi et al. employed a nickel anode current collector layer in their porous zirconia-supported tubular cells, as seen in Figure 11 [110,111]. In their 2017 study, they achieved a current density of $0.8 \mathrm{~A} \cdot \mathrm{cm}^{-2}$ at $0.7 \mathrm{~V}$ and a peak current density of $2 \mathrm{~A} \cdot \mathrm{cm}^{-2}$ operating in $\mathrm{H}_{2}$ at $750{ }^{\circ} \mathrm{C}$. The impedance at OCV under the same conditions was $0.44 \Omega \cdot \mathrm{cm}^{2}$. 


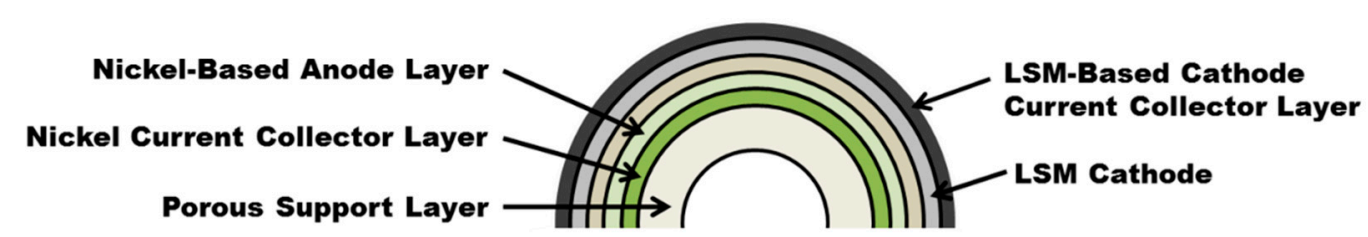

Figure 11. Nickel anode current collecting layer with a porous support cell adapted from [110].

Zhao et al. [112] also adopted a nickel current conduction layer in their "inert-substratesupported" cells. They studied the effect of increasing the current conducting layer thickness, finding that thickening the layer was favourable for the electrochemical performance but not for the redox stability of the cell. For their optimal design, they achieved a current density at $0.7 \mathrm{~V}$ of $0.63 \mathrm{~A} \cdot \mathrm{cm}^{-2}$ with a peak power density of $2.5 \mathrm{~A} \cdot \mathrm{cm}^{-2}$ in dry $\mathrm{H}_{2}$ at $800{ }^{\circ} \mathrm{C}$. The ASR recorded at OCV at the same operating conditions was $0.75 \Omega \cdot \mathrm{cm}^{2}$. The degradation rate was $4 \mathrm{mVh}^{-1}$ over 11 redox cycles.

Kikuta et al. [113] looked into varying the ratio of thickness between a porous nickel anode current collecting layer and the anode, fixing the total thickness to $250 \mu \mathrm{m}$. The cell was a closed-end tube, single-chamber design, meaning anode current collection was only possible from one end of the tube. They achieved a significant improvement with even the thinnest, $20 \mu \mathrm{m}$ of current collecting layer, increasing the peak power density over four-fold from 0.12 to $0.52 \mathrm{~W} \cdot \mathrm{cm}^{-2}$. This allowed them to reduce the thickness of their anode and current collector layer to 50 and $100 \mu \mathrm{m}$, achieving $0.6 \mathrm{~W} \cdot \mathrm{cm}^{-2}$ from this design.

Li et al. [114] developed a dual-layered, hollow fibre cell fabricated by a phaseinversion assisted coextrusion methodology. They were able to achieve great control over the morphology of the nickel current conduction and Ni-YSZ anode microstructure. The objective was to improve the electrical conductivity and reduce the resistance to mass transfer throughout the cell; the former was quantified, observing a two-fold increase in electrical conductivity over a cell with no current collector layer as seen in Figure 12a. They formed finger-like protrusions in the axial (seen in Figure 12b) and radial dimensions of the anode and current collector to establish a mesh-like 3D structure.

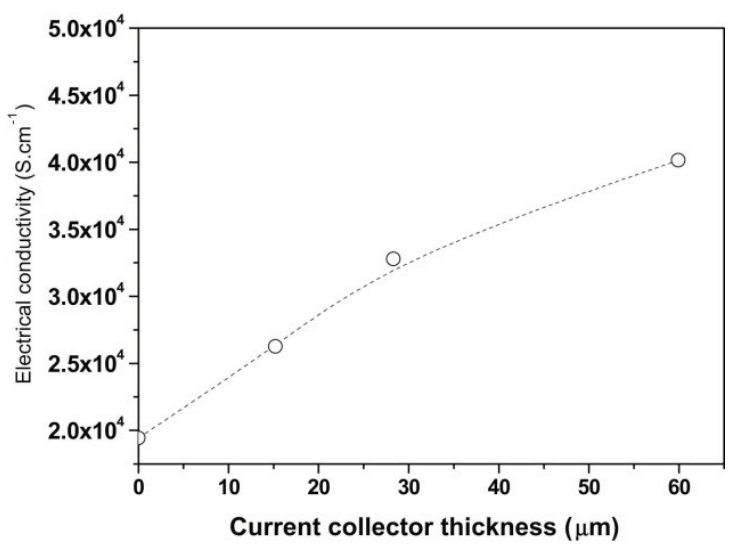

(a)

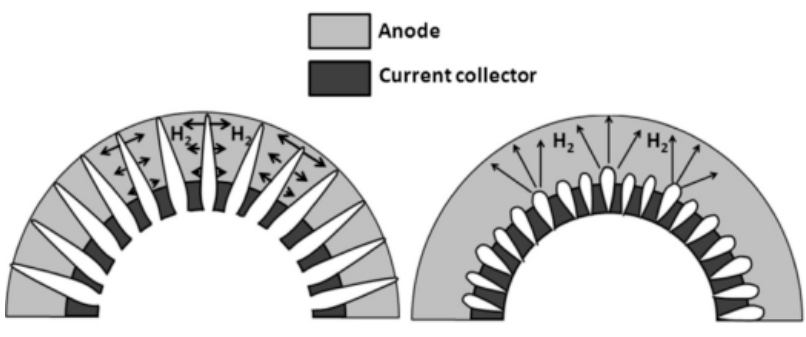

(b)

Figure 12. (a) Electrical conductivity as a function of current collector thickness [114]. (b) Cross-section schematic of dual-layer hollow fibre cell with mesh/finger-like protrusions for enhanced mass transport [114].

\subsection{Meshes}

For nearly 15 years, metallic meshes have been successfully used for electrode contacting both $\mu$ T-SOFC electrodes $[115,116]$. Meshes can be made by hatching wire into a network or bought preformed with a range of thicknesses and mesh aperture sizes available. Meshes achieve a high cross-sectional contacting area without considerably increasing the diameter of the cell. This is particularly important on the outer electrode, allowing more 
compact spacing for cells in stacks. Bore side meshes must be selected carefully so as not to block the flow of gas through the tube to the electrode surface.

Problems can occur on the anode side in anode-supported cells due to the metal sagging as a result of a reduction in elasticity with an increase in temperature. The sagging results in loss of contact with the anode wall at high temperatures leading to a decrease in electrochemical performance, durability and reliability of the cell. Contact force, controlled by mechanical compression in planar devices, is known to be a key factor in optimising interconnect performance and is crucial for minimising contact resistance. To overcome these issues, slide pins and other mesh supports are in development. Meshes can also be secured with conductive pastes and better integrated into the electrode surface itself with the likes of a metal oxide slurry, such as $\mathrm{NiO}$ on the anode, or with current collecting layers such as lanthanum strontium cobalt ferrite (LSCF) [117] on the cathode side.

In 2017, Park et al. [118] used a nickel mesh secured by a nickel paste on the anode side with a Crofer 22 mesh secured with an LSC paste on the cathode side. They compared the performance of the bare mesh with a $1.2 \mu \mathrm{m}$ electrodeposited dual-layered coating. The mesh, with fine wires of $100 \mu \mathrm{m}$ in diameter, was first applied with a $\mathrm{Co}_{3} \mathrm{O}_{4}$ spinel layer followed by a $\mathrm{LaMnO}_{3}$ perovskite layer. The bare mesh achieved a current density at $0.7 \mathrm{~V}$ of 0.5 and $0.52 \mathrm{~A} \cdot \mathrm{cm}^{-2}$ for the virgin and coated mesh, respectively, at $800{ }^{\circ} \mathrm{C}$. The ohmic polarisation and ASR at OCV were 0.26 and $0.79 \Omega \cdot \mathrm{cm}^{2}$ for the coated Crofer and 0.34 and $0.81 \Omega \cdot \mathrm{cm}^{2}$ for the uncoated. The authors measured the increase in ohmic resistance over $1000 \mathrm{~h}$ of the bare versus coated Crofer mesh via impedance spectroscopy. Relative to a virgin sample, the ohmic degradation was reduced nearly 5 -fold from $6.7 \times 10^{-2} \% \cdot \mathrm{h}^{-1}$ to $1.4 \% \cdot \mathrm{h}^{-1}$.

In 2015, Laguna-Becero et al. [119] achieved the highest current density of a tubular cell with a nickel, bore side anode mesh. The design achieved a current density at $0.7 \mathrm{~V}$ of $0.6,0.99$ and $1.15 \mathrm{~A} \cdot \mathrm{cm}^{-2}$ at 750,800 and $850{ }^{\circ} \mathrm{C}$, respectively. Platinum wire and paste were used on the cathode. The fuel and fuel flow rate were not disclosed. At $750{ }^{\circ} \mathrm{C}$, the ohmic polarisation and ASR at OCV were 0.12 and $1.10 \Omega \cdot \mathrm{cm}^{2}$, respectively.

A recent study where a nickel anode side mesh and a silver cathode mesh were used as current collectors was reported by Liu et al. [116] in 2020. Operating on $\mathrm{H}_{2}$, the current density at $0.7 \mathrm{~V}$ was $0.52 \mathrm{~A} \cdot \mathrm{cm}^{-2}$ at $850{ }^{\circ} \mathrm{C}$. The ASR of the cell was $0.1 \Omega \cdot \mathrm{cm}^{2}$.

In 2020, Khan et al. [120] used silver mesh on both the anode and cathode sides for a flattened-tube cell design. On the anode side, silver mesh, silver wire and a silver-glass contact/sealing paste were used. On the cathode side, silver mesh, silver wire and LSC contact/sealing paste were used. At $800{ }^{\circ} \mathrm{C}$, the current density at $0.7 \mathrm{~V}$ was $0.65 \mathrm{~A} \cdot \mathrm{cm}^{-2}$ and the peak current density was $1.55 \mathrm{~A} \cdot \mathrm{cm}^{-2}$.

An anode side silver mesh for a tubular design was reported by Cui et al. [121] in 2020. The cell produced a current density at $0.7 \mathrm{~V}$ of $0.21 \mathrm{~A} \cdot \mathrm{cm}^{-2}$ and a peak power density of $0.17 \mathrm{~W} \cdot \mathrm{cm}^{-2}$ at $800^{\circ} \mathrm{C}$. A silver mesh was used for cathode contacting.

A tubular cell using a silver-based mesh was reported by Chen et al. [122]. The current density at $0.7 \mathrm{~V}$ and $750{ }^{\circ} \mathrm{C}$ was $0.21 \mathrm{~A} \cdot \mathrm{cm}^{-2}$ and peak power density $1.07 \mathrm{~W} \cdot \mathrm{cm}^{-2}$. They used silver mesh and silver wire on both the anode and cathode sides of their cell with a proton-conducting $\mathrm{BZCYYb}$ electrolyte.

\subsection{Foams}

Foam inserts, essentially a highly porous expanded 3D mesh, are a solution to avoid pressure drops and flow disturbances that anode side meshes can have while achieving a large cross-sectional contact patch for current collection. Loss of contact between foams and the cell wall from sagging has not been reported/studied in the literature and is unlikely due to the ease in shaping, allowing the foam to fully fill the tube bore, analogous to a filter inside a cigarette. The filling of the tube will reduce the conduction pathway within the current collector in the radial direction compared to a mesh, for example. Foams are characterised by a high mechanical strength and low weight, favourable for a portable fuel cell device interconnect [123]. The foams are typically made of silver, nickel or steel 
alloys and have been shown in recent literature to exhibit excellent current collecting capabilities [124]. In 2017, Huang et al. [125] reported a current density at $0.7 \mathrm{~V}$ and $750{ }^{\circ} \mathrm{C}$ in $\mathrm{H}_{2}$ of $0.95 \mathrm{~A} \cdot \mathrm{cm}^{-2}$ with a peak power density of $1 \mathrm{~W} \cdot \mathrm{cm}^{-2}$, achieving $24 \mathrm{~W}$ from a single cell. The cell had an outer diameter of $9 \mathrm{~mm}$ and was $100 \mathrm{~mm}$ in length. They performed a degradation study over $4000 \mathrm{~h}$, operating at $18.5 \mathrm{~A}$ with a fuel utilisation of $64.38 \%$ observing a degradation rate of $26 \mathrm{mV} \cdot \mathrm{kh}^{-1}$. The ASR estimated from the polarisation plot at $750{ }^{\circ} \mathrm{C}$ was $0.27 \Omega \cdot \mathrm{cm}^{2}$.

The high surface area to volume ratio of foams positions them as an ideal candidate as a catalyst support, increasing the functionality of the current collector. The catalyst can either be alloyed into the base material during fabrication or added postfabrication by doping. Typical dopants include metals such as copper, cobalt, nickel, manganese and tin. Recent studies into doping have shed light on the possibility to control anode side degradation from coke deposition and increase tolerance to sulphur derivatives [126]. The improved tolerance leads to improved fuel flexibility for operation on lower purity hydrocarbon fuels such as syngas and sour gas [127]. Yan et al. [128] developed a phosphorous doped nickel foam for current collection. When compared to a bare mesh, they observed an improved electrochemical performance and durability under operation under syngas for coatings with phosphorous contents above $6.4 \%$. Weight loss was negligible for the plated mesh sample, compared to the approximately $250 \%$ weight gain observed for samples exposed (ex situ) to syngas for $50 \mathrm{~h}$ at $750{ }^{\circ} \mathrm{C}$.

\subsection{Brush Type}

Brush-type interconnects are structured wire forms that are inserted into the bore of the inner electrode of a tubular cell. Patents published by AMI reveal an internal interconnect with the option for increased functionality when doped with a catalyst [129]. Nevertheless, no experimental results or analysis have been published in the literature. The design has an ordered, axially repeating floral-like cross-section. The brush loops are attached to a central core wire which emerges from the tube end for interconnection. Figure 13a,b show the AMI brush type current collector design with a labelled schematic adapted from AMI [129] shown in (c). The electron flow path is in the radial direction and is noncircumferential, as in a mesh, as the shortest path is from the electrode-interconnect joint of the loop tributary to the central core, which acts as a highway for the electrons. Increasing the number of loops in a given length will also reduce current conduction pathways in the axial dimension. Coiled wires are reported in the patent for cathode current collection and can be an extension of the anode wire from the interior or joined to a different wire of a different material.

Materials inside the tube bore such as brushes, coil meshes and foam types will certainly impact on the fluid flow, causing turbulence and better mixing at the expense of an increase in pressure drop [130]. The aforementioned will likely enhance heat transfer within the cell, primarily from convection but also conduction when contacted to the wall [131]. An increase in radial velocity is also likely, improving mass transport through the cell. A study by Rahimi et al. showed an increase of $41 \%$ in electrochemical performance from a polymer electrolyte membrane (PEM) fuel cell with a coil insert inside the fuel channels when compared to an empty channel [132]. They used a combined experimental and modelling approach and attributed the electrochemical improvement to an increase in tangential fluid velocity that resulted in better transport of reactant from the mainstream to the reaction zone. 


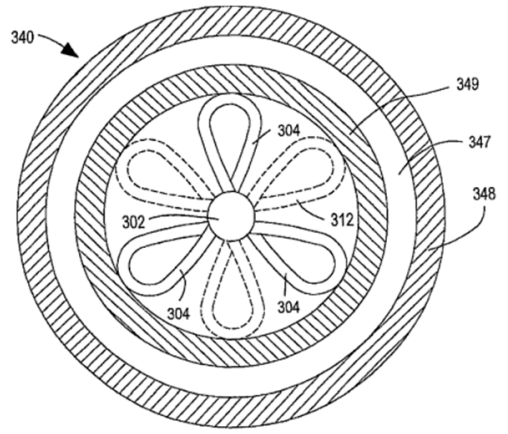

(a)

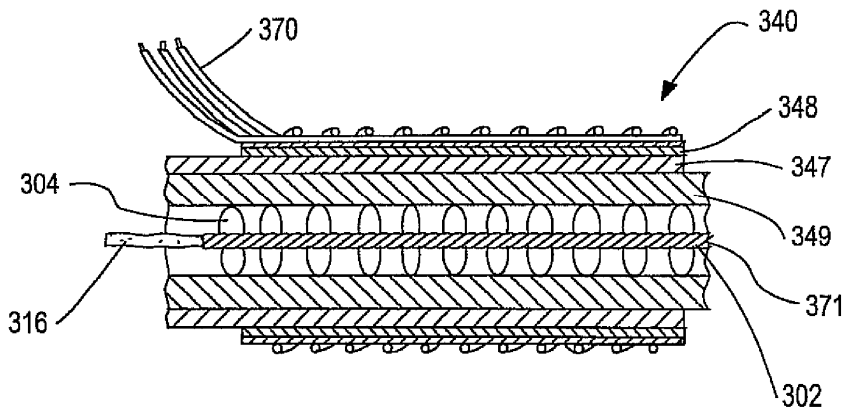

(b)

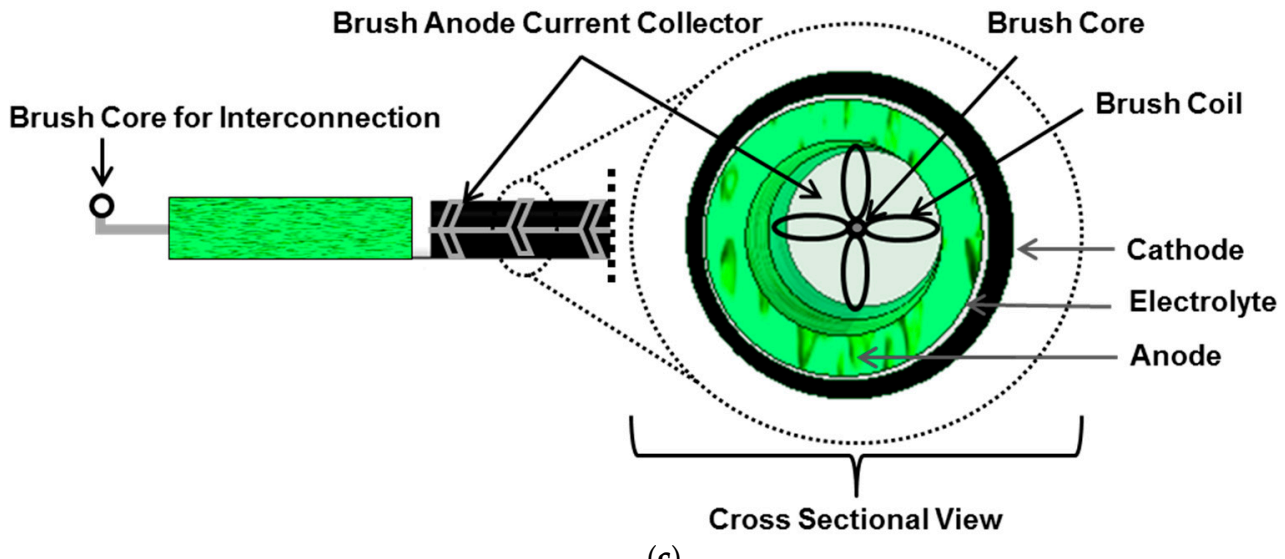

(c)

Figure 13. Brush current collector: (a) AMI design front view, (b) AMI design side view, and (c) schematic in a tubular cell with cross-sectional view adapted from AMI [129].

\subsection{Structurally Integrated/Embedded}

A novel interconnection methodology was first reported by De la Torre et al. [133] in 2011 and later in 2013 [134]. The design involved the integration of current collector wires into the anode support during the manufacturing process as seen in Figure 14b. The wire is coiled around a sacrificial central support pin (pencil led/carbon fibre) and then "dip-coated" with layers of the anode. The wire passes through the entire length of the anode and protrudes from either end of the tube.

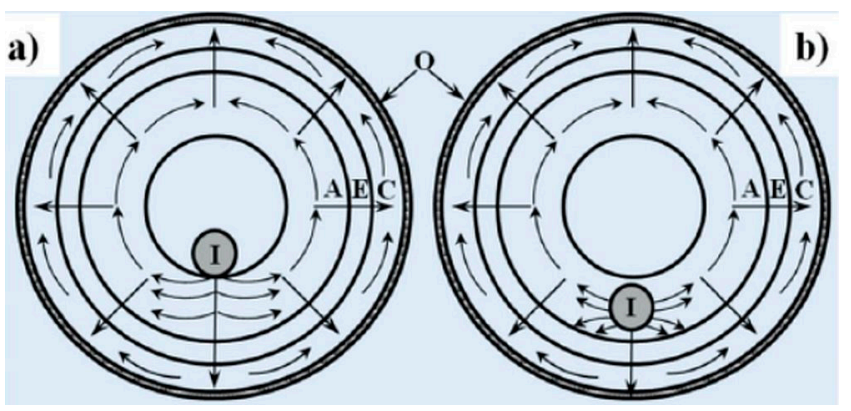

Figure 14. (a) Internal current collector and (b) embedded current collector, where A, C, E and O refer to the anode, electrolyte, cathode and outer current collector, respectively [134].

Electrochemical performance of two cells with the internal and embedded designs seen in Figure $14 \mathrm{a}, \mathrm{b}$, respectively, were reported. At $750{ }^{\circ} \mathrm{C}$, operating on dry $\mathrm{H}_{2}$, the embedded wire achieved a current density of $0.15 \mathrm{~A} \cdot \mathrm{cm}^{-2}$ at $0.7 \mathrm{~V}$. This was a 3.8 -fold increase in performance when compared to the internal current collector wire as seen in Figure $14 \mathrm{a}$, which achieved $0.04 \mathrm{~A} \cdot \mathrm{cm}^{-2}$. Under the same conditions, the peak power 
densities were 0.035 and $0.142 \mathrm{~W} \cdot \mathrm{cm}^{-2}$ for designs a) and b), respectively. The ASR of the embedded cell as estimated from the gradient of the polarisation curve was $1.74 \Omega \cdot \mathrm{cm}^{2}$. The configuration allowed for current collection along the entirety of the anode length, ensuring a well-distributed anode electron conduction profile. The option to collect the current from either end of the cell will approximately halve the lateral current conduction pathway of electrons in the wire compared to a single end connection, also reducing the axial path length. Integrating the wire into the anode ensured sound mechanical contacting and might have somewhat shielded the wire from the harsh gas stream environments. However, some concern surrounded the difference in CTE of the nickel wire and the $\mathrm{Ni}$-YSZ anode which could lead to bending and cracking of the anode, the wire and the surrounding fuel cell components, leading to failure [135].

In 2015, Casarin et al. [136] looked into the effect of coiling anode-embedded, nickel and palladium wires, versus an embedded straight wire. They changed the number of coil rotations (coil density) in a given length to increase the surface area and amount of wire available for collecting current. They found that increasing the nickel wire coil density (by $83 \%$ ) from six turns.cm ${ }^{-1}$ to 11 turns. $\mathrm{cm}^{-1}$ significantly increased the performance. They observed a 3.5-fold increase in current density at $0.7 \mathrm{~V}$ and $800{ }^{\circ} \mathrm{C}$ from 0.055 to $0.19 \mathrm{~A} \cdot \mathrm{cm}^{-2}$, citing a more homogenous current distribution and an increased contact area resulting in lower ohmic polarisation as the root causes. The ASR of the 11 turns.cm ${ }^{-1}$ nickel wire as estimated from the gradient of the polarisation curve was $1.6 \Omega \cdot \mathrm{cm}^{-2}$ at $800{ }^{\circ} \mathrm{C}$. The palladium wires broke, which did not allow a direct comparison between materials and number of coils. However, the authors tested a (nonembedded) palladium wire which achieved a similar current density of $0.2 \mathrm{~A} \cdot \mathrm{cm}^{-2}$ at $0.7 \mathrm{~V}$ and $800{ }^{\circ} \mathrm{C}$ operating temperature when compared to the 11 turns.cm ${ }^{-1}$ nickel wire. The authors claimed that the palladium enhanced the catalytic activity of the anode, resulting in a higher performance. They did not attribute any difference in performance to the different conductivity of materials even though palladium is $35 \%$ more conductive than nickel at $20{ }^{\circ} \mathrm{C}$ and $6.8 \%$ more conductive at $750{ }^{\circ} \mathrm{C}$.

\section{Current Collector Sizing, Spacing and Positioning}

It is intuitive to expect that current collection from a larger area of the electrode will decrease the ohmic losses of a cell. Contacting the entirety of the electrode, however, is unfeasible, blocking fuel transport to the electrode as well as increasing weight and cost. Depending on the configuration, maximising the current collecting area and thus minimising ohmic loss could lead to a loss of available active area which will reduce the total amount of current that can be produced. Therefore, there is a trade-off in the current collector design concerning the sizing of the current collector node, positioning on the electrode and, if opting for multiple nodes, their spacing. Collecting current from either end of an anode has been common in the literature for externally accessed anode current collectors. As can be seen from Figure 15, this has the effect of shortening the distance that the electrons travel from where they are produced, as compared to a single collection node [135].

\section{Anode Current Collector}
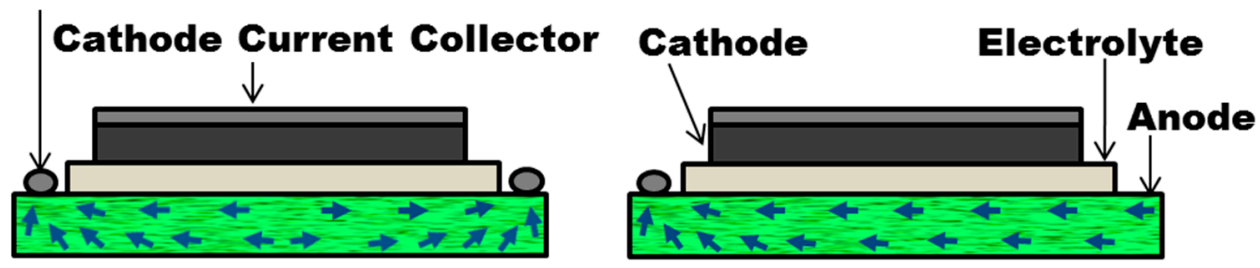

\section{Current Collector at Both Ends Current Collector at One End}

Figure 15. Current conduction pathway for current collection at both ends of the electrode versus one end (blue arrows indicate electron direction). 
As cells become longer, the distance between current collectors at each end of a cell increases and the need for additional current collectors can be justified. Some empirical research has been conducted to determine just how many current collectors are needed for a particular cell length. To do so, the cell is segmented, with multiple current collector nodes spaced along the electrode in question. Although the anode is typically an order of magnitude more conductive than the cathode, nickel-based anode cermets typically have an electronic conductivity of similar order of magnitude (and below) to the conductivity of pure nickel, which is around $2.7 \times 10^{6} \mathrm{~S} \cdot \mathrm{m}^{-1}$ at $750{ }^{\circ} \mathrm{C}$. Values of the effective cermet electronic conductivity reported in the literature vary between $1 \times 10^{6}$ and $1 \times 10^{5} \mathrm{~S} \cdot \mathrm{m}^{-1}$ at typical SOFC operating conditions [137]. Traditional cathodes have relatively lower electronic conductivities compared to the anode at around $1 \times 10^{3} \mathrm{~S} \cdot \mathrm{m}^{-1}$ but more recent mixed ionic-electronic conductors such as LSCF are comparable and can display electronic conductivities up to $1 \times 10^{4} \mathrm{~S} \cdot \mathrm{m}^{-1}$, depending on composition and microstructure [138,139].

Bai et al. [140] looked into determining the optimal number of anode current collectors of their $4.8 \mathrm{~cm}$ long and $7 \mathrm{~mm}$ outer diameter (OD) segmented single-chamber fuel cell. They spaced five current collectors along the length of the cell, creating four active areas connected in series. The geometry and configuration of the current collectors are seen in Figure 16a.

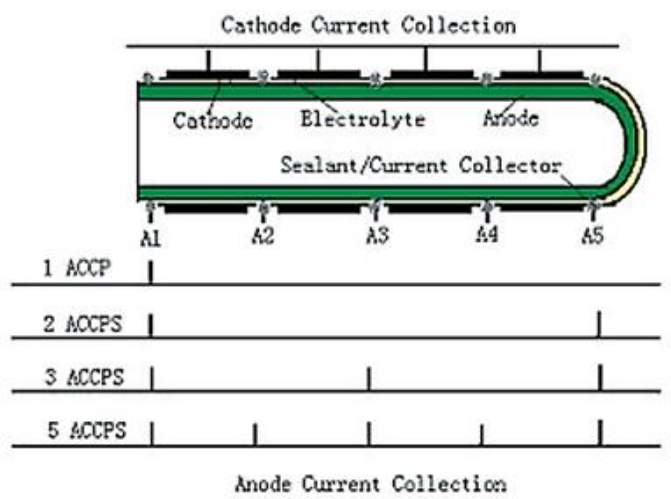

(a)

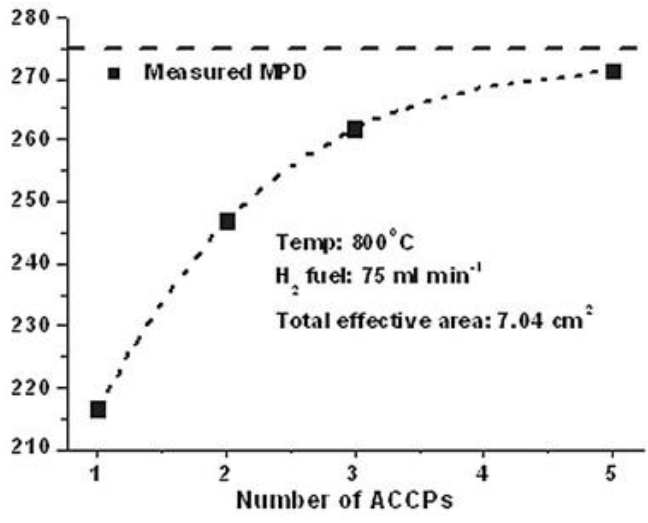

(b)

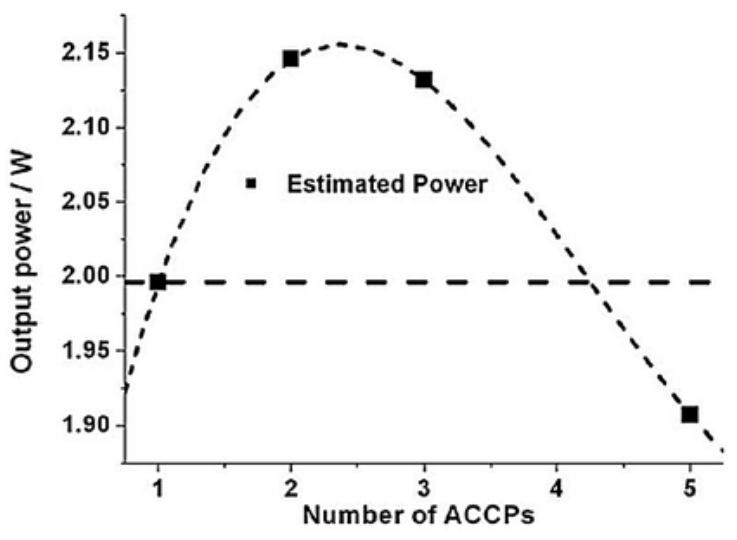

(c)

Figure 16. Segmented tubular cell (a) anode current collector configurations; number of anode current collectors versus (b) maximum power density and (c) total power available from the cell [140].

They found that increasing the number of current collectors from the single inlet and the symmetrically spaced inlet and outlet, inlet and centre and outlet, and then all five positions increased the power density from the cell setup as seen in Figure 16b. They did not, however, look at the effect of the positioning of a single current collector node 
on performance, measuring only the current observed from a single current collector at the inlet. The authors only presented data from 5 of the 31 possible current collector combinations for this setup. They did, however, consider the resulting loss of active area from increasing the number of current collectors, each collector incurring a 5.6\% loss of the total active area available. They used the power density data from their segmented cell to estimate the total power that could be derived from a cell of the same geometry but with a different number of current collectors. They found that two current collectors, one at either end, were the optimal configuration, incurring a penalty of loss of active area and increasing ohmic resistance if they deviated, as seen in Figure 16c.

Contrary to this finding, Meadowcroft et al. [141] found that for their cell geometry, a single current collector node, at the centre of the cell, was superior to that of a cell with multiple anode current collectors, notably two at either end of the active area. The single central current collector incurred a 6 to $9 \%$ (estimated) loss in active area, whereas the two current collectors did not. The geometry of the cell was longer than that of Bai et al. at $152 \mathrm{~mm}$ in length but had a similar diameter of $6.7 \mathrm{~mm}$. Evidently, the cell geometry has a considerable effect when it comes to finding the optimal current collector configuration to maximise the total power from a cell. The experimental data presented in the literature are limited on this subject and more research needs to be conducted to get a better understanding. The data produced must be representative of the typical cell geometries and materials used in tubular SOFCs. Models built from this data could reliably predict the optimum sizing of current collectors for a wide range of cell designs and would be a cost- and time-effective tool.

Shimizu et al. [142] conducted a similar experiment with an anode-supported segmented tubular cell $48 \mathrm{~mm}$ in length and $8 \mathrm{~mm}$ OD. They positioned three $2.5 \mathrm{~cm}^{2}$ cathode segments $2 \mathrm{~mm}$ apart on their in-house fabricated cell. They performed an initial comparison of the cell with all three cathodes connected in parallel to that of a cell with the same active area but with no segmentation and determined that the performance was the same and that the segmentation had no noticeable impact. They compared the performance from each cell segment with 120, 80 and $40 \mathrm{~mL} \cdot \mathrm{min}^{-1}$ total flow rates of equimolar $\mathrm{H}_{2}$ and $\mathrm{N}_{2}$.

For the highest fuel flow rate, they observed a similar performance from all three cell configurations which indicated a homogenous current distribution in the cell and sufficient volumetric flow rate to minimise the effect of concentration polarisation. The current density at $0.7 \mathrm{~V}$, in this case, was around $0.125 \mathrm{~A} \cdot \mathrm{cm}^{-2}$ for the upstream, $0.105 \mathrm{~A} \cdot \mathrm{cm}^{-2}$ for the midstream, and $0.1 \mathrm{~A} \cdot \mathrm{cm}^{-2}$ for the downstream segments, respectively-i.e., values were within $23 \%$ (or less) of each other. Reducing the flow rate resulted in a larger difference of $50 \%$ (or less) between current density values at $0.7 \mathrm{~V}$. The current density of the upstream cell remained at $0.125 \mathrm{~A} \cdot \mathrm{cm}^{-2}$ while the midstream and downstream segments dropped to 0.075 and $0.095 \mathrm{~A} \cdot \mathrm{cm}^{-2}$, respectively. The largest performance decrease of $29 \%$ occurred in the midstream segment. Shimizu et al. ascribed this to a relatively low activation potential at the downstream cell versus midstream cells, arising from improved anode kinetics due to increased partial pressure of water, the reaction product. For the lowest flow rate, the current distribution was highly inhomogeneous, with a difference of $58 \%$ in current density between segments at $0.7 \mathrm{~V}$. The upstream cell was reduced to $0.11 \mathrm{~A} \cdot \mathrm{cm}^{-2}$ whilst the midstream and downstream segments were down to $0.06 \mathrm{~A} \cdot \mathrm{cm}^{-2}$. Increasing the polarisation of the downstream beyond $0.7 \mathrm{~V}$ gave a somewhat unusual result-the peak current density was reached at $0.45 \mathrm{~V}$. Increasing the polarisation beyond this did not increase the current density - in fact, the converse. Meanwhile, the current density of the upstream segment increased to a value higher than for higher flow rates. The starvation of the downstream segment came from the low inlet flow rate, compounded with the consumption of fuel and the increase in reaction product (water) from the upstream and midstream cell segments. The authors also measured the temperature at each segment for the lowest flow rate. The largest temperature rise was for the upstream and midstream segments at $5{ }^{\circ} \mathrm{C}$. 


\section{Effect of Cell Geometry on Current Collection}

An experimental study by Jin et al. [143] showed how the current density at $0.7 \mathrm{~V}$ of a single cell decreased by a third from 1.2 (cell a) to $0.8 \mathrm{~A} \cdot \mathrm{cm}^{-2}$ (cell b) as the distance between the anode current collector and the active region/cathode current collector increased sevenfold. They spaced four electrically isolated "cells" with similar areas along the $150 \mathrm{~mm}$ anode-supported single-chamber cell, as seen in Figure 17.

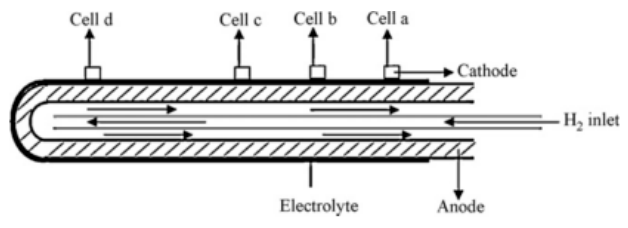

(a)

\begin{tabular}{lcll}
\hline & $d(\mathrm{~cm})$ & Cathode area $\left(\mathrm{cm}^{2}\right)$ & OCVs $\left(800^{\circ} \mathrm{C}\right)(\mathrm{V})$ \\
\hline Cell a & 2 & 0.31 & 1.013 \\
Cell b & 5 & 0.33 & 1.038 \\
Cell c & 8 & 0.30 & 1.050 \\
Cell d & 14 & 0.31 & 1.045 \\
\hline
\end{tabular}

(b)

Figure 17. (a) Current collector configurations and (b) cell specifications [143].

Through impedance spectroscopy, they attributed the difference in performance to an increasing ohmic resistance with length as seen in Figure 18. They observed that the ohmic and total cell resistance followed a similar linear trend whereas the interfacial polarisation did not change significantly between cells, determining that the electrode reaction was not affected by a varying fuel utilisation and therefore changes to the performance were dominated by the ohmic resistance of the anode for these fuelling conditions.

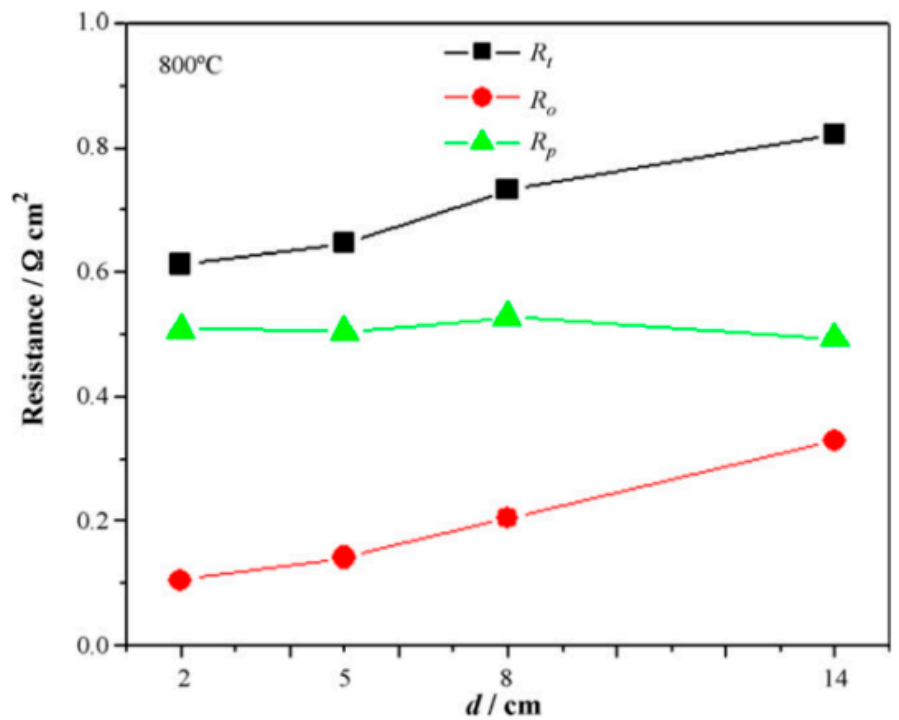

Figure 18. Distribution of $R_{t}, R_{o}$ and $R_{p}$ of the four single cells. $R_{t}$, the total cell resistance; $R_{o}$, the ohmic resistance; $R_{p}$, the interfacial polarization resistance; $d$, the distance between the cathode of the cell and the anode current collecting point [143].

In 2006, Suzuki et al. published two papers that estimated the effect of changing the anode wall thickness on cell resistance for the two geometries of $\mu \mathrm{T}-\mathrm{SOFC}, 1.6 \mathrm{~mm}$ OD and $0.8 \mathrm{~mm}$ OD that were in development $[51,52]$. They based the estimates on impedance and conductivity data they had acquired empirically for each anode at various temperatures. They conducted the study to determine whether it was sufficient to use the anode as the sole current collector-i.e., collection at one end or both ends. They concluded that an anode length of a few centimetres was the limit for such a setup due to increasing ohmic resistance. They stated that careful stack design is of paramount importance to overcome this effect. It was concluded that the anode resistance did not change linearly with wall 
thickness. The data for wall thickness versus cell resistance are seen in Figure 19 for the $0.8 \mathrm{~mm}$ OD tube.

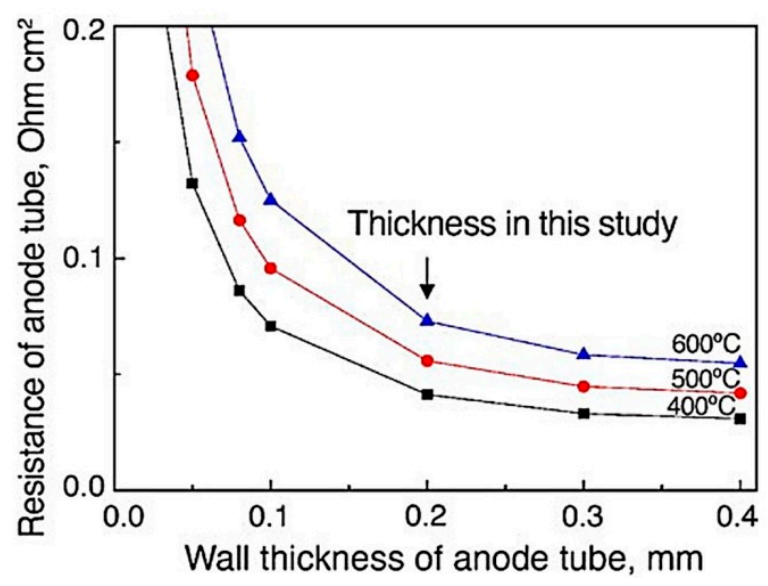

Figure 19. Wall thickness versus area-specific resistance for $12 \mathrm{~mm}$ long $0.8 \mathrm{~mm}$ OD tube [52].

\section{Conclusions and Perspective}

This paper presented an overview of current collection issues in $\mu \mathrm{T}-\mathrm{SOFC}$. The key bottlenecks in $\mu \mathrm{T}$-SOFC technology were discussed with a particular focus on current collection. The metrics of current collector performance were detailed as well as the overall requirements of an optimal design. The effect of current collector size, spacing and positioning on cell performance was studied and the key design trade-offs identified. The nickel mesh internal anode current collector and coated Crofer mesh cathode current collector configuration presented by Park et al. [118] was highlighted as a low-cost, high performing design that did not sacrifice durability.

In order to achieve high cell performance (with a low ASR) and high stability/durability over the cell lifetime, research into $\mu \mathrm{T}-\mathrm{SOFC}$ needs to place greater focus on current collection issues. Divergence should be made from the use of the state-of-the-art silver current collectors to low-cost alternatives given the widely reported durability concerns surrounding mechanical integrity at typical SOFC operating temperatures. Mechanically durable metallic current collectors are available and reduce bulk conductivity and contact resistance while adhering to delivering chemical and CTE compatibility. For a given current collector material, the minimisation of contact resistance between the current collector and the electrode is essential for a low ohmic polarisation. Brazing offers a commercially viable pathway to provide physical joints at multiple current collector-electrode interfaces, reducing contact resistance while also significantly improving durability. Minimisation of contact resistance through the coating of low-cost current collectors with thin layers of highly conductive materials and corrosion-proof material must be explored in more detail. Combining coated low-cost current collectors with physical contacting through brazing would favour a durable and high performing design and present a viable route for progression in the field.

Facile manufacturing and contacting a larger and well-distributed surface area of the inner electrode, thus minimising current conduction pathways, is a key element of $\mu \mathrm{T}-\mathrm{SOFC}$ stack design. Care must be given when matching the current collector material with the current collector design. Both internal and embedded current collectors allow for a higher cell active area and thus a higher total cell power as they do not require any space to be positioned on the cell exterior (where the cathode is located in the typical anode-supported cell configuration). Current collector designs must be reproducible and must consider manufacture and assembly in the design phase. Researchers working in cell testing may have results masked by variation in the current collector design as opposed to their study parameters, for example, in materials development. In addition, researchers must also be aware that long conduction pathways in tubular cells can necessitate multiple 
current collectors per cell for a low ohmic polarisation, particularly for cells with high length to diameter ratios.

Author Contributions: Conceptualization, O.H.-P., A.D., R.S.-W.; investigation, O.H.-P.; resources, O.H.-P., A.D., R.S.-W.; data curation, O.H-P.; writing — original draft preparation, O.H.-P.; writingreview and editing, O.H.-P., A.D., R.S.-W.; visualization, O.H.-P.; supervision, A.D., R.S.-W.; project administration, A.D., R.S.-W.; funding acquisition, R.S.-W. All authors have read and agreed to the published version of the manuscript.

Funding: This research was funded by the EPSRC, grant number EP/L015749/1, through the CDT in Fuel Cells and their Fuels, led by the University of Birmingham.

Data Availability Statement: Data for Figure 5 acquired from https://www.engineeringvillage. $\mathrm{com} /$ search/quick.url using the search thread provided.

Conflicts of Interest: The authors declare no conflict of interest.

\section{References}

1. Bujalski, W.; Dikwal, C.M.; Kendall, P.K. Cycling of three solid oxide fuel cell types. J. Power Sources 2007, 171, 96-100. [CrossRef]

2. Kendall, K.; Kendall, M. High-Temperature Solid Oxide Fuel Cells for the 21st Century: Fundamentals, Design and Applications; Elsevier: London, UK, 2015.

3. Mench, M.M. Fuel Cell Engines; John Wiley \& Sons: Hoboken, NJ, USA, 2008.

4. Boersma, R.J.; Sammes, N.M.; Fee, C.J. Losses resulting from in-plane electricity conduction in tubular solid oxide fuel cells. Solid State Ion. 2000, 135, 493-502. [CrossRef]

5. Bove, R.; Sammes, N.M. The Effect of Current Collectors Configuration on the Performance of a Tubular SOFC. Proc. Electrochem. Soc. 2005, 2005-2007, 780-789. [CrossRef]

6. Kendall, K.; Kendall, M.; Niewolak, L.; Tietz, F.; Quadakkers, W.J. Interconnects. In High-Temperature Solid Oxide Fuel Cells 21st Century; Elsevier: London, UK, 2016; pp. 195-254.

7. Larmine, J.; Dicks, A. Fuel Cell Systems Explained; John Wiley \& Sons: Chichester, UK, 2006.

8. Sharaf, O.Z.; Orhan, M.F. An overview of fuel cell technology: Fundamentals and applications. Renew. Sustain. Energy Rev. 2014, 32, 810-853. [CrossRef]

9. Chen, W. Mobile Applications: Cars, Trucks, locomotives, Marine Vehicles, and Aircraft; Elsevier Inc.: Amsterdam, The Netherlands, 2020. [CrossRef]

10. Singhal, S.C. Solid oxide fuel cells for stationary, mobile, and military applications. Solid State Ion. 2002, 152, 405-410. [CrossRef]

11. Nissan Motor Corporation. Nissan Announces Development of the World's First SOFC-Powered Vehicle System that Runs on Bioethanol Electric Power. 2016. Available online: https:/ /global.nissannews.com/en/releases/160614-01-e?source=nng (accessed on 3 October 2020).

12. Hart, D.; Lehner, F.; Jones, S.; Lewis, J. The Fuel Cell Industry Review 2019. 2019. Available online: www.FuelCellIndustryReview. com (accessed on 1 May 2020).

13. Watanabe, C. Ene-Farms Use Hydrogen to Power Homes but Don't Come Cheap. Bloom. Technol. 2015. Available online: https: / / www.bloomberg.com/news/articles/2015-01-15/fuel-cells-for-homes-japanese-companies-pitch-clean-energy (accessed on 1 August 2020).

14. Plug Power. GENDRIVE Fuel Cells. 2017. Available online: http://www.plugpower.com/products/gendrive/ (accessed on 8 May 2017).

15. Intelligent Energy. Intelligent Energy's Fuel Cells Stacks to be Used in Met Police Zero Emission Scooter Trial. Intell. Energy 2017. Available online: http://www.intelligent-energy.com/news-and-events/company-news/2017/02/07/intelligent-energysfuel-cells-stacks-to-be-used-in-met-police-zero-emission-scooter-trial/ (accessed on 8 May 2017).

16. Barley, S. Hydrogen Bus Launched on London Tourist Route, Guard. 2010. Available online: https://www.theguardian.com/ environment/2010/dec/10/hydrogen-bus-london (accessed on 5 August 2020).

17. Hyundai. Hyundai ix35 Hydrogen Fuel Cell Vehicle. 2017. Available online: http://www.hyundai.co.uk/about-us/environment/ hydrogen-fuel-cell (accessed on 8 May 2017).

18. Toyota. Mirai-Bringing the Future into the Present. 2017. Available online: https://www.toyota.co.uk/new-cars/new-mirai/ landing.json (accessed on 8 May 2017).

19. Fernandes, M.; Andrade, S.D.P.; Bistritzki, V.; Fonseca, R.; Zacarias, L.; Gonçalves, H.; De Castro, A.; Domingues, R.; Matencio, T. SOFC-APU systems for aircraft: A review. Int. J. Hydrog. Energy 2018, 43, 16311-16333. [CrossRef]

20. Mahato, N.; Banerjee, A.; Gupta, A.; Omar, S.; Balani, K. Progress in material selection for solid oxide fuel cell technology: A review. Prog. Mater. Sci. 2015, 72, 141-337. [CrossRef]

21. Jamil, S.M.; Othman, M.H.D.; Rahman, M.A.; Jaafar, J.; Ismail, A.F.; Li, K. Recent fabrication techniques for micro-tubular solid oxide fuel cell support: A review. J. Eur. Ceram. Soc. 2015, 35, 1-22. [CrossRef] 
22. Bianco, M.; Linder, M.; Larring, Y.; Greco, F.; Van Herle, J. Lifetime Issues for Solid Oxide Fuel Cell Interconnects; Elsevier Ltd.: Amsterdam, The Netherlands, 2017. [CrossRef]

23. Tucker, M.C. Progress in metal-supported solid oxide fuel cells: A review. J. Power Sources 2010, 195, 4570-4582. [CrossRef]

24. Zhu, J.H.; Ghezel-Ayagh, H. Cathode-side electrical contact and contact materials for solid oxide fuel cell stacking: A review. Int. J. Hydrog. Energy 2017, 42, 24278-24300. [CrossRef]

25. Shi, H.; Su, C.; Yang, G.; Ran, R.; Hao, Y.; Tadé, M.O.; Shao, Z. Fabrication and operation of flow-through tubular SOFCs for electric power and synthesis gas cogeneration from methane. AIChE J. 2014, 60, 1036-1044. [CrossRef]

26. Lessing, P.A. A review of sealing technologies applicable to solid oxide electrolysis cells. J. Mater. Sci. 2007, 42, 3465-3476. [CrossRef]

27. Singh, R.N. Sealing Technology for Solid Oxide Fuel Cells (SOFC). Int. J. Appl. Ceram. Technol. 2007, 4, 134-144. [CrossRef]

28. Timurkutluk, B.; Timurkutluk, C.; Mat, M.D.; Kaplan, Y. A review on cell/stack designs for high performance solid oxide fuel cells. Renew. Sustain. Energy Rev. 2016, 56, 1101-1121. [CrossRef]

29. Lawlor, V.; Griesser, S.S.; Buchinger, G.; Olabi, A.; Cordiner, S.; Meissner, D. Review of the micro-tubular solid oxide fuel cell Part I. Stack design issues and research activities. J. Power Sources 2009, 193, 387-399. [CrossRef]

30. Howe, K.S.; Thompson, G.J.; Kendall, K. Micro-tubular solid oxide fuel cells and stacks. J. Power Sources 2011, 196, 1677-1686. [CrossRef]

31. Brett, D.J.L.; Atkinson, A.; Brandon, N.; Skinner, S.J. Intermediate temperature solid oxide fuel cells. Chem. Soc. Rev. 2008, 37, 1568-1578. [CrossRef]

32. Kendall, K.; Kendall, M.; Minh, N.Q. Cell and stack design, fabrication and performance. In High-Temperature Solid Oxide Fuel Cells 21st Century; Elsevier: London, UK, 2016; pp. 255-282.

33. Wachsman, E.D.; Lee, K. Lowering the Temperature of Solid Oxide Fuel Cells. Science 2011, 334, 935-939. [CrossRef]

34. Zhu, W.; Deevi, S. Development of interconnect materials for solid oxide fuel cells. Mater. Sci. Eng. A 2003, 348, 227-243. [CrossRef]

35. Rodriguez-Martinez, L.M.; Rivas, M.; Otaegi, L.; Gomez, N.; Alvarez, M.A.; Sarasketa-Zabala, E.; Manzanedo, J.; Burgos, N.; Castro, F.; Laresgoiti, A.; et al. Tubular Metal Support Solid Oxide Fuel Cell Manufacturing and Characterization. ECS Trans. 2011, 35, 445-450. [CrossRef]

36. Haberman, B.A.; Marquis, A.J. A Numerical Investigation into the Interaction between Current Flow and Fuel Consumption in a Segmented-in-Series Tubular SOFC. J. Fuel Cell Sci. Technol. 2009, 6, 031002. [CrossRef]

37. Vora, S.D. SECA Program at Siemens Westinghouse, Presented at SECA Annual Workshop and Peer Review Meeting. 2004. Available online: https:/ / www.osti.gov/scitech/servlets/purl/834189\#page=41 (accessed on 20 August 2020).

38. Kendall, M.; Meadowcroft, A.D.; Kendall, K. Microtubular Solid Oxide Fuel Cells (mSOFCs). ECS Trans. 2013, 57, 123-131. [CrossRef]

39. Kendall, K. Introduction to SOFCs. In High-Temperature Solid Oxide Fuel Cells 21st Century; Elsevier: London, UK, $2016 ;$ pp. 1-24.

40. Sin, Y.; Galloway, K.; Roy, B.; Sammes, N.M.; Song, J. The properties and performance of micro-tubular (less than 2.0 mm O.D.) anode suported solid oxide fuel cell (SOFC). Int. J. Hydrog. Energy 2011, 36, 1882-1889. [CrossRef]

41. Ren, C.; Gan, Y.; Yang, C.; Lee, M.; Xue, X. Fabrication and Characterization of Direct Methane Fueled Thin Film SOFCs Supported by Microchannel-Structured Microtubular Substrates. ACS Appl. Energy Mater. 2020, 3, 1831-1841. [CrossRef]

42. Kendall, K.; Meadowcroft, A. Improved ceramics leading to microtubular Solid Oxide Fuel Cells (mSOFCs). Int. J. Hydrog. Energy 2013, 38, 1725-1730. [CrossRef]

43. Mukerjee, S.; Leah, R.; Selby, M.; Stevenson, G.; Brandon, N.P. Life and Reliability of Solid Oxide Fuel Cell-Based Products. In Solid Oxide Fuel Cell Lifetime and Reliability; Elsevier Ltd.: Amsterdam, The Netherlands, 2017; pp. 173-192. [CrossRef]

44. Hart, D.; Lehner, F.; Rose, R.; Lewis, J.; Klippenstein, M. The Fuel Cell Industry Review 2015; E4Ttech: London, UK, 2015.

45. Kraftwek. 2017. Available online: https://www.kickstarter.com/projects/ezelleron/kraftwerk-highly-innovative-portablepower-plant (accessed on 4 April 2017).

46. Kendall, K.; Kendall, M.; Adler, S.B. Sources of cell and electrode polarisation losses in SOFCs. In High-Temperature Solid Oxide Fuel Cells 21st Century; Elsevier: London, UK, 2016; pp. 357-381. [CrossRef]

47. Hatchwell, C.; Sammes, N.; Kendall, K. Cathode current-collectors for a novel tubular SOFC design. J. Power Sources 1998, 70, 85-90. [CrossRef]

48. Hatchwell, C.; Sammes, N.M.; Brown, I.W.M.; Kendall, K. Current collectors for a novel tubular design of solid oxide fuel cell. J. Power Sources 1999, 77, 64-68. [CrossRef]

49. Kilbride, I.P. Preparation and properties of small diameter tubular solid oxide fuel cells for rapid start-up. J. Power Sources 1996, 61, 167-171. [CrossRef]

50. Kendall, K.; Palin, M. A small solid oxide fuel cell demonstrator for microelectronic applications. J. Power Sources 1998, 71, 268-270. [CrossRef]

51. Suzuki, T.; Yamaguchi, T.; Fujishiro, Y.; Awano, M. Improvement of SOFC Performance Using a Microtubular, Anode-Supported SOFC. J. Electrochem. Soc. 2006, 153, 925-928. [CrossRef]

52. Suzuki, T.; Yamaguchi, T.; Fujishiro, Y.; Awano, M. Fabrication and characterization of micro tubular SOFCs for operation in the intermediate temperature. J. Power Sources 2006, 160, 73-77. [CrossRef] 
53. Dhir, A.; Kendall, K. Microtubular SOFC anode optimisation for direct use on methane. J. Power Sources 2008, 181, 297-303. [CrossRef]

54. Dhir, A. Improved Microtubular Solid Oxide Fuel Cells. Ph.D. Thesis, University of Birmingham, Birmingham, UK, 2008.

55. Dhir, A.; Kendall, K. Improving Reliability of Microtubular SOFCs for Direct Use on Methane. ECS Trans. 2007, 7, 823-828. [CrossRef]

56. Kendall, K. Progress in solid oxide fuel cell materials. Int. Mater. Rev. 2005, 50, 257-264. [CrossRef]

57. Fu, Y.; Bazant, M.Z. Theoretical and Experimental Study of Solid Oxide Fuel Cell (SOFC) Using Impedance Spectra. Ph.D. Thesis, Massachusetts Institute of Technology, Cambridge, MA, USA, 2014.

58. Wu, J.; Liu, X. Recent Development of SOFC Metallic Interconnect. J. Mater. Sci. Technol. 2010, 26, 293-305. [CrossRef]

59. Fergus, J.W. Metallic interconnects for solid oxide fuel cells. Mater. Sci. Eng. A 2005, 397, 271-283. [CrossRef]

60. Kong, W.; Li, J.; Liu, S.; Lin, Z. The influence of interconnect ribs on the performance of planar solid oxide fuel cell and formulae for optimal rib sizes. J. Power Sources 2012, 204, 106-115. [CrossRef]

61. Fergus, J.W. Lanthanum chromite-based materials for solid oxide fuel cell interconnects. Solid State Ion. 2004, 171, 1-15. [CrossRef]

62. Badwal, S.P.; Zhang, J. Interaction between chromia forming alloy interconnects and air. Solid State Ion. 1997, 99, 297-310. [CrossRef]

63. Brandner, L.S.S.M.; Bienertb, C.; Megela, S.; Kusnezoffa, M.; Trofimenkoa, N.; Sauchuka, V.; Venskutonisb, A.; Krausslerb, W.; Michaelis, A. Long Term Performance of Stacks with Chromium-based Interconnects (CFY). ECS Trans. 2013, 57, $2235-2244$. [CrossRef]

64. Niewolak, L.; Wessel, E.; Singheiser, L.; Quadakkers, W.J. Potential suitability of ferritic and austenitic steels as interconnect materials for solid oxide fuel cells operating at $600{ }^{\circ}$ C. J. Power Sources 2010, 195, 7600-7608. [CrossRef]

65. Casteel, M. Hybrid Materials Design for SOFC Interconnect Applications. Ph.D. Thesis, Rensselaer Polytechnic Institute, Troy, NY, USA, 2012.

66. Hammer, J.E.; Laney, S.J.; Jackson, R.W.; Coyne, K.; Pettit, F.S. The Oxidation of Ferritic Stainless Steels in Simulated Solid-Oxide Fuel-Cell Atmospheres. Oxid. Met. 2007, 67, 1-38. [CrossRef]

67. Jablonski, P.D.; Alman, D.E. Oxidation resistance and mechanical properties of experimental low coefficient of thermal expansion (CTE) Ni-base alloys. Int. J. Hydrog. Energy 2007, 32, 3705-3712. [CrossRef]

68. Sakai, N.; Yokokawa, H.; Horita, T.; Yamaji, K. Lanthanum Chromite-Based Interconnects as Key Materials for SOFC Stack Development. Int. J. Appl. Ceram. Technol. 2005, 1, 23-30. [CrossRef]

69. Linder, M.; Hocker, T.; Holzer, L.; Friedrich, K.A.; Iwanschitz, B.; Mai, A.; Schuler, J.A. Model-based prediction of the ohmic resistance of metallic interconnects from oxide scale growth based on scanning electron microscopy. J. Power Sources 2014, 272, 595-605. [CrossRef]

70. Blennow, P.; Hjelm, J.; Klemensø, T.; Ramousse, S.; Kromp, A.; Leonide, A.; Weber, A. Manufacturing and characterization of metal-supported solid oxide fuel cells. J. Power Sources 2011, 196, 7117-7125. [CrossRef]

71. Zhao, F.; Virkar, A.V. Dependence of polarization in anode-supported solid oxide fuel cells on various cell parameters. J. Power Sources 2005, 141, 79-95. [CrossRef]

72. Finsterbusch, M. Degradation Mechanisms of Solid Oxide Fuel Cell Cathodes. Ph.D. Thesis, Technische Universität Ilmenau, Ilmenau, Germany, 2011.

73. Froitzheim, J.; Canovic, S.; Nikumaa, M.; Sachitanand, R.; Johansson, L.; Svensson, J.-E. Long term study of Cr evaporation and high temperature corrosion behaviour of Co coated ferritic steel for solid oxide fuel cell interconnects. J. Power Sources 2012, 220, 217-227. [CrossRef]

74. Singh, P.; Yang, Z.; Viswanathan, V.; Stevenson, J.W. Observations on the Structural Degradation of Silver during Simultaneous Exposure to Oxidizing and Reducing Environments. J. Mater. Eng. Perform. 2004, 13, 287-294. [CrossRef]

75. Wu, J.; Johnson, C.D.; Gemmen, R.S.; Liu, X. The performance of solid oxide fuel cells with Mn-Co electroplated interconnect as cathode current collector. J. Power Sources 2009, 189, 1106-1113. [CrossRef]

76. Mukerjee, S.; Haltiner, K.; Kerr, R.; Chick, L.; Sprenkle, V.; Meinhardt, K.; Lu, C.; Kim, J.Y.; Weil, K.S. Solid Oxide Fuel Cell Development: Latest Results. ECS Trans. 2007, 7, 59-65. [CrossRef]

77. Minh, N.Q. Ceramic Fuel Cells. J. Am. Ceram. Soc. 1993, 76, 563-588. [CrossRef]

78. Aydin, O.; Nakajima, H.; Kitahara, T. Processes Involving in the Temperature Variations in Solid Oxide Fuel Cells In-Situ Analyzed through Electrode-Segmentation Method. J. Electrochem. Soc. 2015, 163, F216-F224. [CrossRef]

79. Compson, C.; Songho, C.; Abermathy, H.; Choi, Y.-M.; Meilin, L. Stability and performance of silver in an SOFC interconnect environment. In Proceedings of the 31st International Conference on Advanced Ceramics and Composites, Daytona Beach, FL, USA, 21-26 January 2007; pp. 301-312.

80. Akhtar, N.; Decent, S.P.; Kendall, K. Structural stability of silver under single-chamber solid oxide fuel cell conditions. Int. J. Hydrog. Energy 2009, 34, 7807-7810. [CrossRef]

81. Majewski, A.J.; Dhir, A. Application of silver in microtubular solid oxide fuel cells. Mater. Renew. Sustain. Energy 2018, 7, 16. [CrossRef]

82. Cambridge Press. Materials Data Book, 2003 Editi; Cambridge University Engineering Department: Cambridge, UK, 2003.

83. Ding, J.; Zhou, X.; Liu, Q.; Yin, G. Development of tubular anode-supported solid oxide fuel cell cell and 4-cell-stack based on lanthanum gallate electrolyte membrane for mobile application. J. Power Sources 2018, 401, 336-342. [CrossRef] 
84. Zhu, H.; Kee, R.J.; Janardhanan, V.M.; Deutschmann, O.; Goodwin, D.G. Modeling Elementary Heterogeneous Chemistry and Electrochemistry in Solid-Oxide Fuel Cells. J. Electrochem. Soc. 2005, 152, A2427-A2440. [CrossRef]

85. Sudagar, J.; Lian, J.; Sha, W. Electroless nickel, alloy, composite and nano coatings-A critical review. J. Alloys Compd. 2013, 571, 183-204. [CrossRef]

86. Parkinson, R. Properties and Applications of Electroless Nickel. Nickel Dev. Inst. 1997, 37, 1-33. Available online: https: //www.nickelinstitute.org/media/1769/propertiesandapplicationsofelectrolessnickel_10081_.pdf (accessed on 5 February 2020).

87. Curtis, L. Electroforming_Jewellery Handbooks; Bloomsbury Publishing PLC: London, UK, 2004.

88. Fan, P.; Li, G.; Zeng, Y.; Zhang, X. Numerical study on thermal stresses of a planar solid oxide fuel cell. Int. J. Therm. Sci. 2014, 77, 1-10. [CrossRef]

89. Lin, C.; Chen, T.; Chyou, Y.; Chiang, L. Thermal stress analysis of a planar SOFC stack. J. Power Sources 2007, 164, 238-251. [CrossRef]

90. ThyssenKrupp, V.D.M. Crofer 22 APU-Material Data Sheet No. 4046; ThyssenKrupp VDM: Hongkong, China, 2010.

91. Ottersted, R. Electrolyte for Cost-Effective, Electrolyte-Supported High-Temperature Fuel Cell Having High Performance and High Mechanical Strength. U.S. Patent 9,136,553 B2, 15 September 2015.

92. Haynes International. HAYNES ${ }^{\circledR} 230^{\circledR}$ Alloy, Data Sheet. 2020. Available online: http:/ / haynesintl.com/docs/default-source/ pdfs/new-alloy-brochures/high-temperature-alloys/brochures/230-brochure.pdf (accessed on 1 January 2020).

93. Linderoth, S.; Hendriksen, P.V.; Mogensen, M.; Langvad, N. Investigations of metallic alloys for use as interconnects in solid oxide fuel cell stacks. J. Mater. Sci. 1996, 31, 5077-5082. [CrossRef]

94. Greiner, H. Chromium based Alloys for High Temperature SOFC Applications. ECS Proc. 1995, 1995-1, 879-888. [CrossRef]

95. Sammes, N.M.; Du, Y.; Bove, R. Design and fabrication of a $100 \mathrm{~W}$ anode supported micro-tubular SOFC stack. J. Power Sources 2005, 145, 428-434. [CrossRef]

96. AZO Materials, Azo Materials, Silver-Applications and Properties of Silver. 2001. Available online: https://www.azom.com/ properties.aspx?ArticleID=600 (accessed on 1 January 2021).

97. The Alloys Network, Properties, Fabrication and Applications of Commercially Pure Nickel. 2020. Available online: https: / / www.nickel-alloys.net/article/commercially-pure-properties.html (accessed on 18 September 2020).

98. Merker, J.; Lupton, D.; Töpfer, M.; Knake, H. High temperature mechanical properties of the platinum group metals: Elastic properties of platinum, rhodium and iridium and their alloys at high temperatures. Platin. Met. Rev. 2001, 45, 74-82.

99. AZO Materials, AZO Materials, Gold-Properties and Applications of Gold. 2001. Available online: https://www.azom.com/ properties.aspx?ArticleID=598 (accessed on 1 January 2021).

100. AZO Materials, AZO Materials, an Introduction to Palladium. 2001. Available online: https://www.azom.com/properties.aspx? ArticleID=1339 (accessed on 1 January 2021).

101. Jiang, S.P.; Love, J.G.; Apateanu, L. Effect of contact between electrode and current collector on the performance of solid oxide fuel cells. Solid State Ion. 2003, 160, 15-26. [CrossRef]

102. Kendall, K.; Kendall, M.; Kendall, K. Portable early market SOFCs. In High-Temperature Solid Oxide Fuel Cells 21st Century; Elsevier: London, UK, 2016; pp. 329-356.

103. Rabuni, M.F.; Vatcharasuwan, N.; Li, T.; Li, K. High performance micro-monolithic reversible solid oxide electrochemical reactor. J. Power Sources 2020, 458, 228026. [CrossRef]

104. Hornes, A.; Torrell, M.; Morata, A.; Kendall, M.; Kendall, K.; Tarancon, A.; Road, P.H. Towards a high fuel utilization and low degradation of micro-tubular solid oxide fuel cells. Int. J. Hydrog. Energy 2017, 42, 13889-13901. [CrossRef]

105. Kendall, K.; Kendall, M.; Cassidy, M.; Connor, P.A.; Irvine, J.T.S.; Savaniu, C.D. Anodes. In High-Temperature Solid Oxide Fuel Cells 21st Century; Elsevier: Amsterdam, The Netherlands, 2016; pp. 133-160. [CrossRef]

106. Kendall, K.; Kendall, M.; Kawada, T.; Horita, T. Cathodes. In High-Temperature Solid Oxide Fuel Cells 21st Century; Elsevier: Amsterdam, The Netherlands, 2016; pp. 161-193.

107. Durango-Petro, J.; Usuba, J.; Valle, H.; Abarzua, G.; Flies, H.; Udayabhaskar, R.; Mangalaraja, R.V. Ascendable method for the fabrication of micro-tubular solid oxide fuel cells by ram-extrusion technique. Ceram. Int. 2020, 46, 2602-2611. [CrossRef]

108. Laguna-Bercero, M.A.; Monzón, H.; Larrea, A.; Orera, V. Improved stability of reversible solid oxide cells with a nickelate-based oxygen electrode. J. Phys. Chem. A 2015, 4, 1446-1453. [CrossRef]

109. Laguna-Bercero, M.A.; Luebbe, H.; Silva, J.; Van Herle, J. Electrochemical Performance of Nd1.95NiO4+8Cathode supported Microtubular Solid Oxide Fuel Cells. Fuel Cells 2014, 15, 98-104. [CrossRef]

110. Panthi, D.; Choi, B.; Tsutsumi, A. Direct methane operation of a micro-tubular solid oxide fuel cell with a porous zirconia support. J. Solid State Electrochem. 2016, 21, 255-262. [CrossRef]

111. Panthi, D.; Choi, B.; Tsutsumi, A. A Novel Micro-Tubular Solid Oxide Fuel Cell with a Porous Zirconia Support for IntermediateTemperature Operation. ECS Trans. 2015, 68, 2259-2265. [CrossRef]

112. Zhao, K.; Kim, B.H.; Xu, Q.; Du, Y.; Ahn, B.G. Redox cycling performance of inert-substrate-supported tubular single cells with nickel anode current collector. J. Power Sources 2015, 293, 336-342. [CrossRef]

113. Kikuta, K.; Yasue, K.; Suzuki, M.; Kanehira, S.; Kirihara, S. Design and fabrication of micro close end tubular SOFC with internal conduction layer. J. Ceram. Soc. Jpn. 2016, 124, 360-364. [CrossRef]

114. Li, T.; Wu, Z.; Li, K. A dual-structured anode/Ni-mesh current collector hollow fibre for micro-tubular solid oxide fuel cells (SOFCs). J. Power Sources 2014, 251, 145-151. [CrossRef] 
115. Kendall, P.K.; Slinn, M.; Preece, J. Formulating liquid ethers for microtubular SOFCs. J. Power Sources 2006, 157, 750-753. [CrossRef]

116. Liu, C.; Pu, J.; Chen, X.; Ma, Z.; Ding, X.; Zhou, J.; Wang, S. Influence of anode's microstructure on electrochemical performance of solid oxide direct carbon fuel cells. Int. J. Hydrog. Energy 2020, 45, 11784-11790. [CrossRef]

117. Hanifi, A.R.; Paulson, S.; Torabi, A.; Shinbine, A.; Tucker, M.C.; Birss, V.; Etsell, T.H.; Sarkar, P. Slip-cast and hot-solution infiltrated porous yttria stabilized zirconia (YSZ) supported tubular fuel cells. J. Power Sources 2014, 266, 121-131. [CrossRef]

118. Park, B.; Song, R.; Lee, S.; Lim, T.; Park, S.; Jung, W.; Lee, J. Conformal bi-layered perovskite/spinel coating on a metallic wire network for solid oxide fuel cells via an electrodeposition-based route. J. Power Sources 2017, 348, 40-47. [CrossRef]

119. Laguna-Bercero, M.A.; Hanifi, A.R.; Etsell, T.H.; Sarkar, P.; Orera, V.M. Microtubular solid oxide fuel cells with lanthanum strontium manganite infiltrated cathodes. Int. J. Hydrog. Energy 2015, 40, 5469-5474. [CrossRef]

120. Khan, M.Z.; Song, R.-H.; Hussain, A.; Lee, S.-B.; Lim, T.-H.; Hong, J.-E. Effect of applied current density on the degradation behavior of anode-supported flat-tubular solid oxide fuel cells. J. Eur. Ceram. Soc. 2020, 40, 1407-1417. [CrossRef]

121. Cui, D.; Ji, Y.; Chang, C.; Wang, Z.; Xiao, X. Influence of fuel flow rate on the performance of micro tubular solid oxide fuel cell. Int. J. Hydrog. Energy 2020, 45, 13459-13468. [CrossRef]

122. Chen, C.; Dong, Y.; Li, L.; Wang, Z.; Liu, M.; Rainwater, B.H.; Bai, Y. Electrochemical properties of micro-tubular intermediate temperature solid oxide fuel cell with novel asymmetric structure based on BaZr0.1Ce0.7Y0.1Yb0.1O3- $\delta$ proton conducting electrolyte. Int. J. Hydrog. Energy 2019, 44, 16887-16897. [CrossRef]

123. Banhart, J. Manufacture, characterisation and application of cellular metals and metal foams. Prog. Mater. Sci. 2001, 46, 559-632. [CrossRef]

124. Lee, I.-S.; Park, M.-H.; Jun, J.-H.; Park, C.-R.; Kim, B.-S.; Lee, C.-W.; Choi, S.-H. Cathode Current Collector for Solid Oxide Fuel Cell, and Solid Oxide Fuel Cell Compromising same. U.S. Patent 2017/0005345 A1, 5 January 2017.

125. Huang, W.; Finnerty, C.; Sharp, R.; Wang, K.; Balili, B. High-Performance 3D Printed Microtubular Solid Oxide Fuel Cells. Adv. Mater. Technol. 2017, 2. [CrossRef]

126. Troskialina, L.; Dhir, A.; Steinberger-Wilckens, R. Improved Performance and Durability of Anode Supported SOFC Operating on Biogas. ECS Trans. 2015, 68, 2503-2513. [CrossRef]

127. Fu, X.Z.; Melnik, J.; Low, Q.X.; Luo, J.; Chuang, K.T.; Sanger, A.R.; Yang, Q.M. Surface modified Ni foam as current collector for syngas solid oxide fuel cells with perovskite anode catalyst. Int. J. Hydrog. Energy 2010, 35, 11180-11187. [CrossRef]

128. Yan, N.; Fu, X.-Z.; Luo, J.; Chuang, K.T.; Sanger, A.R. Ni-P coated Ni foam as coking resistant current collector for solid oxide fuel cells fed by syngas. J. Power Sources 2012, 198, 164-169. [CrossRef]

129. Crumm, A.; Shuck, Q.; Rice, J. Solid Oxide Fuel Cell with Improved Current Collection. U.S. Patent 8,343,689 B2, 1 January 2013.

130. Helgadóttir, Á.; Lalot, S.; Beaubert, F.; Pálsson, H. Mesh Twisting Technique for Swirl Induced Laminar Flow Used to Determine a Desired Blade Shape. Appl. Sci. 2018, 8, 1865. [CrossRef]

131. Naga Sarada, S.; Radha, K.K.; Raju, A.V.S. Experimental investigations in a circular tube to enhance turbulent heat transfer using mesh inserts. J. Eng. Appl. Sci. 2009, 4, 53-60.

132. Rahimi, M.; Aghel, B.; Alsairafi, A. Chemical Engineering and Processing: Process Intensification Experimental and CFD studies on using coil wire insert in a proton exchange membrane fuel cell. Chem. Eng. Process. Process Intensif. 2010, 49, 688-695. [CrossRef]

133. De la Torre, R.; Sglvado, V. Fabrication of Innovative Compliant Current Collector-Supported Microtubular Solid Oxide Fuel Cells. Int. J. Appl. Ceram. Technol. 2011, 9, 1058-1063. [CrossRef]

134. De La Torre, R.; Avila-Paredes, H.J.; Sglavo, V.M. Comparative Performance Analysis of Anode-Supported Micro-Tubular SOFCs with Different Current-Collection Architectures. Fuel Cells 2013, 13. [CrossRef]

135. De la Torre García, R. Production of Micro-Tubular Solid Oxide Fuel Cells. Ph.D. Thesis, University of Trento, Trento, Italy, 2011.

136. Casarin, M.; Sglavo, V.M. Effect of the Current Collector on Performance of Anode-Supported Microtubular Solid Oxide Fuel Cells. J. Fuel Cell Sci. Technol. 2015, 12, 031005. [CrossRef]

137. Celik, A.N. Three-dimensional multiphysics model of a planar solid oxide fuel cell using computational fluid dynamics approach. Int. J. Hydrog. Energy 2018, 43, 19730-19748. [CrossRef]

138. Jeon, D.H. A comprehensive CFD model of anode-supported solid oxide fuel cells. Electrochim. Acta 2009, 54, 2727-2736. [CrossRef]

139. Navasa, M.; Graves, C.; Chatzichristodoulou, C.; Løye, T.; Sund, B. A three dimensional multiphysics model of a solid oxide electrochemical cell: A tool for understanding degradation. Int. J. Hydrog. Energy 2018, 43, 11913-11931. [CrossRef]

140. Bai, Y.; Wang, C.; Jin, C.; Liu, J. Anode Current Collecting Efficiency of Tubular Anode-supported Solid Oxide Fuel Cells. Fuel Cells 2011, 11, 465-468. [CrossRef]

141. Meadowcroft, A.; Howe, K.; Dhir, A.; Steinberger-Wilckens, R. Connection Optimisation for Micro-Tubular Solid Oxide Fuel Cells (A1507). In Proceedings of the 11th European SOFC \& SOE Forum, Lucerne, Switzerland, 1-7 July 2014.

142. Shimizu, A.; Nakajima, H.; Kitahara, T. Current Distribution Measurement of a Microtubular Solid Oxide Fuel Cell. ECS Trans. 2013, 57, 727-732. [CrossRef]

143. Jin, C.; Liu, J.; Li, L.; Bai, Y. Electrochemical properties analysis of tubular NiO-YSZ anode-supported SOFCs fabricated by the phase-inversion method. J. Membr. Sci. 2009, 341, 233-237. [CrossRef] 